$10-2021$

\title{
Through the Ivory Curtain: African Americans in Cleveland Heights, Ohio, before the Fair Housing Movement
}

J. Mark Souther

Cleveland State University, m.souther@csuohio.edu

Follow this and additional works at: https://engagedscholarship.csuohio.edu/clhist_facpub

Part of the African American Studies Commons, Race and Ethnicity Commons, Social History

Commons, Social Policy Commons, United States History Commons, and the Urban Studies and Planning Commons

How does access to this work benefit you? Let us know!

Publisher's Statement

This article published in the SAGE Journal of Urban History

\section{Repository Citation}

Souther, J. Mark, "Through the Ivory Curtain: African Americans in Cleveland Heights, Ohio, before the Fair Housing Movement" (2021). History Faculty Publications. 121.

https://engagedscholarship.csuohio.edu/clhist_facpub/121

This Article is brought to you for free and open access by the History Department at EngagedScholarship@CSU. It has been accepted for inclusion in History Faculty Publications by an authorized administrator of EngagedScholarship@CSU. For more information, please contact library.es@csuohio.edu. 


\section{Through the Ivory Curtain: African \\ Americans in Cleveland Heights, \\ Ohio, before the Fair Housing \\ Movement}

\section{J. Mark Souther}

In 1957, Urban League of Cleveland secretary K. C. Jones spoke at a housing conference called by the Cleveland City Council's urban redevelopment committee. Jones assured those assembled that they were "completely able, if willing, to strike down the ivory curtain which is at present surrounding the city and preventing qualified colored citizens from living in a location of their choice." With the "ivory curtain," Jones adapted Cold War imagery to dramatize the racial separation between the city and its suburbs. Suburban exclusion was real, but as Cleveland Heights Mayor Ken Nash observed later, "We've always had a number of Negro families in the Heights. And this is one of the things that people don't understand." Nash insisted that Cleveland Heights did not face the "problem" that neighboring East Cleveland and Shaker Heights were having with absorbing black buyers from adjacent Cleveland neighborhoods, thanks to the steep, wooded hill on the suburb's western edge, which one Cleveland Heights councilman called a "natural buffer." Still, they were not taking chances. Nash, whose administration worked "behind the scenes to buffer our community," lauded an urban renewal plan to demolish large homes along the suburb's 
border to expand the Western Reserve University campus, thereby removing the specter of rooming houses. Despite the long presence of a few African American homeowners and many nonowner residents, Cleveland Heights leaders feared the racial change they saw around them. ${ }^{2}$

Such was the prevailing view from behind the ivory curtain as Cleveland's growing black population clamored for better housing and as a handful of progressive suburbanites began to pursue fair housing policies in response to white panic, resegregation, and disinvestment. The formation of the Heights Citizens for Human Rights in 1964 and activists' efforts to foster housing choice made Cleveland Heights (like Shaker Heights) a national model of managed integration by the 1970 s, but it is nonetheless necessary to examine the history of African American domestic workers, custodians, renters, and homeowners who lived there before that time. ${ }^{3}$ The legacy of their persistence contrasted with the example of Parma on Cleveland's West Sidewhose almost total absence of blacks as late as 1980 impeded integration — and it helped lay the foundation for a more successful integration of the Heights. ${ }^{4}$

If the continuous presence of African Americans in the suburb, as Nash observed, was already little known in the 1960s, it has been virtually absent in historical accounts. Why? As will become apparent, only once in the sixty years before 1960 did it appear that black homeownership might exceed the token presence of about one home per square mile. In addition, after the Great Migration created what historian Andrew Wiese would dub a "domestic service suburb" with hundreds of live-in servants, Cleveland Heights saw its servant population decline slowly in the 1930 s-40s and rapidly in the 1950 s until its black population was only 251 out of 61,813 in $1960 .{ }^{5}$ Finally, those who succeeded in lifting the ivory curtain before the 1960 s did little to hold it up for others, focusing instead on their professional, social, and domestic lives.

This examination of black suburban life in the decades before substantive racial integration uncovers a complex, mostly hidden story of how African American live-in servants, apartment building custodians, renters, and homeowners fared in the previously largely white suburb. It provides rare insight into the partial autonomy that resident janitors seized for themselves, as well as the possibilities and risks of breaking the color line that homeowners confronted in collaboration with white intermediaries. Blacks who occupied Cleveland Heights houses and apartments in this period were fragmented by class and geography, which constrained their expectations for what suburban living might bring. Rather than presenting themselves as the vanguard of racial integration, they sought more personal rewards such as the wages of domestic labor, better housing, and quality education for their children. Nevertheless, their presence spaded the ground for later advances.

Why Cleveland Heights? After all, Shaker Heights was nationally known as a master-planned, deed-restricted suburb by the 1920s and gained further distinction in 1963 when Cosmopolitan highlighted it as the wealthiest community in the United States. The suburb's Ludlow district appeared in Reader's Digest after residents created a novel program to counter the profiteering real estate brokers who stoked white fear of racial transition. ${ }^{6}$ Once its government embraced a managed integration stance, Shaker enjoyed a reputation as a suburb that maintained high standards while becoming socially diverse. Thanks to its high profile, Shaker Heights integration has attracted much scholarly attention over the past thirty years. ${ }^{7}$ In contrast, Cleveland Heights has seen considerably less attention, and nearly all focuses on the period since the $1960 \mathrm{~s}^{8}$ The story of black suburbanization in Cleveland Heights before the fair housing movement has been largely unwritten, even though the first black homeowners settled there in 1923, two years before the better-known example of Dr. E. A. Bailey in Shaker Heights. ${ }^{9}$

Unlike the well-documented fair housing and managed integration initiatives of the 1960s-1970s, it is daunting to reconstruct earlier African American experiences in the Heights. By piecing together fragmentary sources, it is nonetheless possible to sketch at least impressionistic portraits of black suburban residents, including those who had little chance of securing homes outside of domestic or custodial service and those who defied the odds to establish 
independent rented or owned homes. ${ }^{10}$ Though many details remain shrouded, the black press, manuscript censuses, city directories, property records, and court cases inform a previously untold story.

Most African Americans in Cleveland Heights and Shaker Heights were live-in servants as late as the mid-20th century. Still, many achieved some independence as resident apartment building janitors, and a few secured apartments without a custodial arrangement or even homeownership. Black homeowners sometimes provoked violent white reactions, but most clung to hard-fought gains and remained for years or even decades. Although live-in domestics rarely had children living with them, a handful of apartment dwellers and homeowners with children took advantage of the suburb's public schools. Live-in domestic service work eroded in the 1940s-1950s as Cleveland Heights approached its peak population, rendering blacks increasingly invisible and, when visible, alarming to many whites. The few lingering black homeowners and renters nonetheless constituted a thread to the nascent organized struggle for fair housing.

\section{The Early Development of a First-ring Suburb}

As in other U.S. cities, Cleveland annexed land through the late nineteenth century but made fewer territorial gains thereafter. Where its city limits abutted East Cleveland Township, the last annexation absorbed the Little Italy neighborhood in 1892 . Beyond the city limits, East Cleveland and Cleveland Heights incorporated as villages in 1895 and 1903, respectively. Growth in East Cleveland outpaced that of Cleveland Heights atop the bluff to its south and east. By 1910, East Cleveland counted more than 9,000 residents, while Cleveland Heights had yet to reach 3,000. Most early development in Cleveland Heights occurred in its western part on the bluff above the lake plain. Beginning in 1890, Patrick Calhoun, the grandson of Vice President and Senator John C. Calhoun of South Carolina who became better known for his consolidation of a streetcar monopoly in San Francisco ten years later, paired construction of a streetcar line from University Circle to a fashionable residential allotment he named Euclid Heights, which attracted some of Cleveland's wealthy to "the Overlook" in its first decade. Yet only a scattering of mansions dotted this upland moor as late as 1900 . Shaker Heights, planned by railroad barons Oris P. and Mantis J. Van Sweringen, soon got underway to the south, reinforcing the sluggish development of Euclid Heights by offering another alternative to the old "Millionaires' Row" along Euclid Avenue. By 1914, after Calhoun defaulted on his development, forcing a sheriff's sale of unbuilt lots, his dream of grand estates yielded to more intensive and varied development. As a result, the population of Cleveland Heights soared to 15,236 by 1920 , more than tripled to 50,945 by 1930 , and then grew slowly to a peak of 61,813 by 1960 as open land disappeared. ${ }^{11}$

Not all black newcomers to northern cities in the Great Migration landed in emerging "ghettos" such as Cleveland's Cedar-Central, as Andrew Wiese and Todd Michney have shown (see Figure 1). Many went straight to outlying enclaves such as Mt. Pleasant, Miles Heights, and Chagrin Falls Park. Others took jobs in the Heights as live-in servants or apartment building janitors. ${ }^{12}$ The black population of Cleveland Heights soared from 37 in 1910 to 571 in 1930 , before contracting to 251 thirty years later (see Figure 2). One indication of the impact of the Great Migration is the fact that at least 81 of 185 African Americans in Cleveland Heights in 1920 were born in the South. ${ }^{13}$ Thus, Cleveland's eastern suburbs were never solidly white even if black homeownership was rare in the first half of the century.

\section{Live-in Servants}

The first African American residents of Cleveland Heights lived in some of the thirty-odd houses built in Euclid Heights around the turn of the century. Fifteen black servants lived in five mansions on or near the Overlook in 1900. Patrick Calhoun employed seven of them. Calhoun, his 


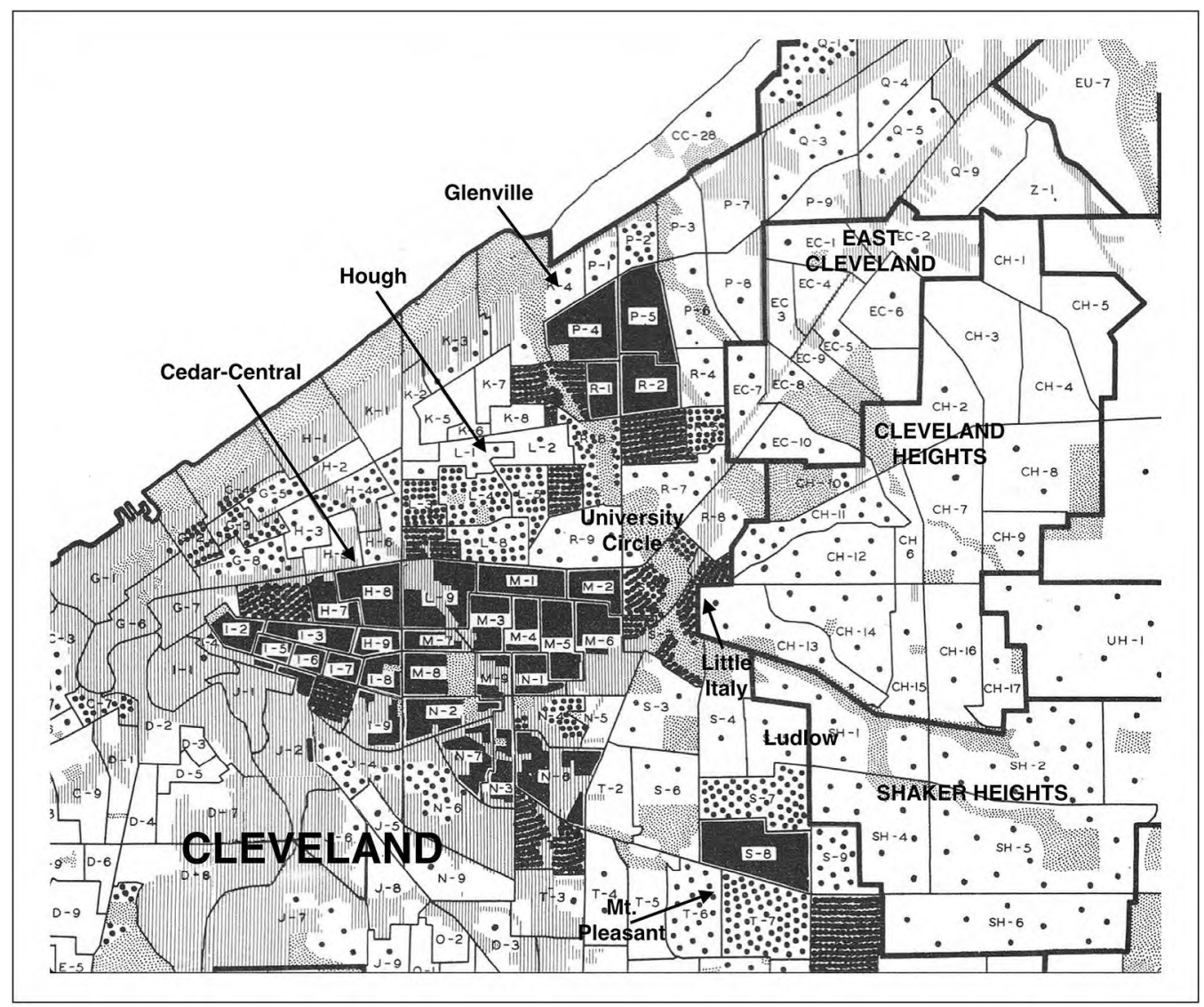

Figure I. Black population in Cleveland and Eastern Suburbs, 1950.

Source: Adapted from Howard Whipple Green, Real Property Inventory, | 951 , Cleveland State University Library Special Collections. Each dot represents ten black residents. The dots are evenly distributed within census tracts.

wife Sally, and their eight children lived in a mansion at 2460 Edgehill Road, completed in 1898. Jane Robinson, a seventy-two-year-old widowed servant, was formerly enslaved on John C. Calhoun's Fort Hill plantation in Clemson, South Carolina. Robinson's eight grandchildren accompanied Patrick and Sally Calhoun to Cleveland, and in 1900 three of them, Priest Robinson, a butler, and Ella and Mary Robinson, both child nurses, were listed in their employ (see Figure 3). The Calhouns' gardener, George Wiggins, also came from Calhoun's home state, and a third child nurse, Emma Bratcher, hailed from Georgia. ${ }^{14}$

Ten years later, census enumerators found thirty-seven "Black" or "Mulatto" residents in Cleveland Heights. They comprised almost 1.3 percent of the village's population, the highest proportion until the 1960s. Twenty-six (70 percent) were servants in private homes, including seventeen in Euclid Heights. Two were servants at the Euclid Club, Cleveland's second-oldest golf club, and another seven men worked as teamsters or stable hands in a paving contractor's Mayfield Road encampment. Two others were not located in the manuscript census. ${ }^{15}$ The number of live-in servants and their dependents soared to 389 in 1930. However, live-in service fluctuated as more African Americans availed themselves of emerging opportunities to live in the suburb at least semi-autonomously as janitors and, less commonly, as independent renters or homeowners.

In 1920, one year before the village incorporated as a city, the census found 185 African Americans. It is unclear how many moved directly to the suburb, but of those who arrived before 


\begin{tabular}{|c|c|c|}
\hline Year & $\begin{array}{c}\text { Black Pop. } \\
\text { (Pop. in manuscript census) }\end{array}$ & \% of Total Pop. \\
\hline 1900 & $15(15)$ & 1.0 \\
\hline 1910 & $37(35)$ & 1.3 \\
\hline 1920 & $185(153)$ & 1.2 \\
\hline 1930 & $571(571)$ & 1.1 \\
\hline 1940 & $511(476)$ & 0.9 \\
\hline 1950 & 434 (NA) & 0.7 \\
\hline 1960 & 251 (NA) & 0.4 \\
\hline
\end{tabular}

Figure 2. Cleveland Heights Black population, 1900-1960. The vast majority of African Americans in Cleveland Heights were live-in servants or building custodians throughout this sixty-year period. The effects of the Great Migration and the rapid growth of Cleveland's suburbs are apparent in the large increases in the 1910s and 1920s. Residential domestic service declined steadily after the 1930s. Fair housing efforts in the 1960s would produce the first substantial presence of black homeowners by 1970 . Source: U.S. Census. Notes: Cleveland Heights was not incorporated in 1900. Therefore, the figure for 1900 represents the Euclid Heights allotment, whose addresses appear in the manuscript census for East Cleveland Township. Legibility issues, especially in the 1920 and 1940 manuscript censuses, account for the variance between total figures and those analyzed.

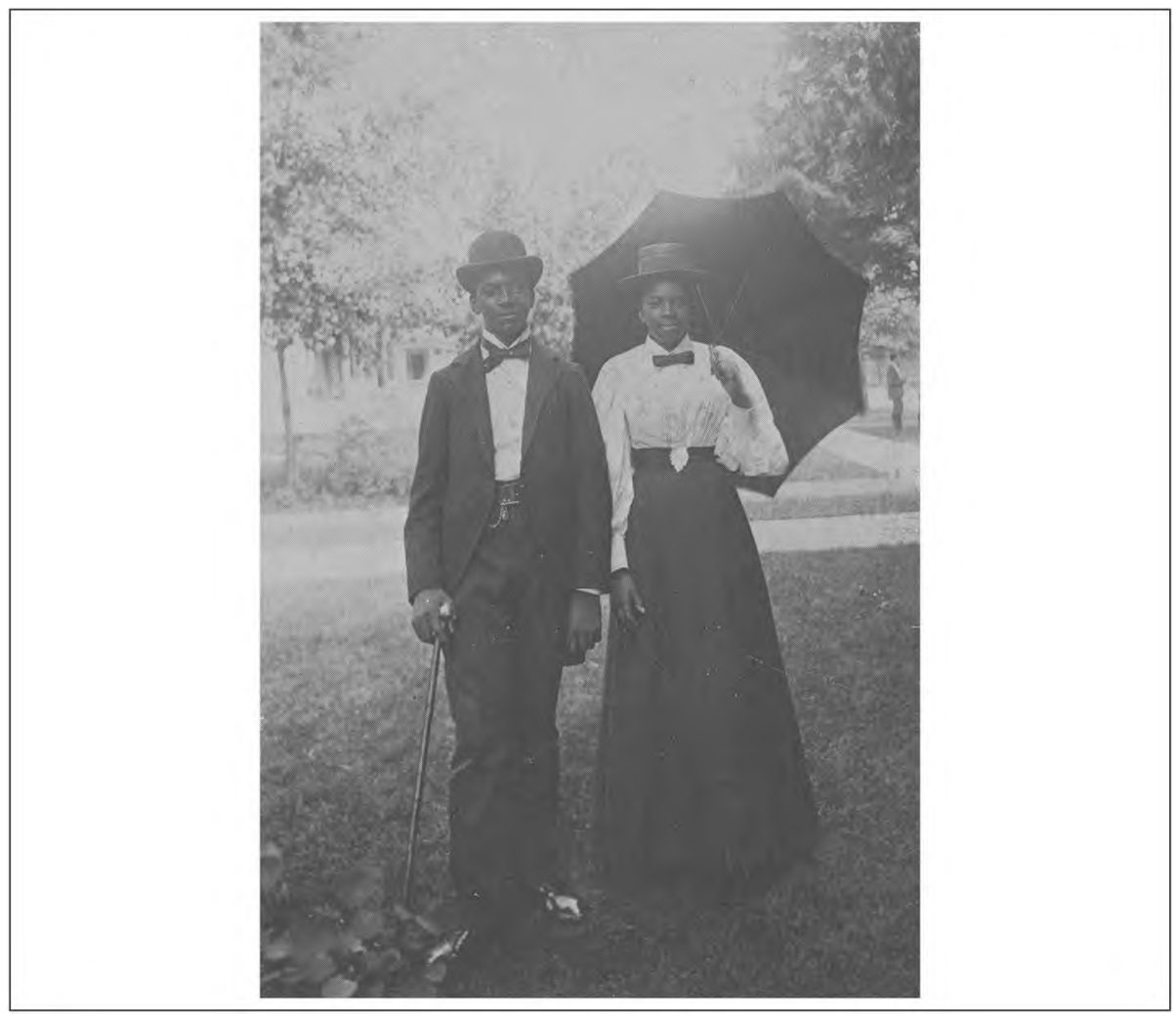

Figure 3. Priest and Mary Robinson in Cleveland Heights, ca. 1900. The Robinson siblings worked as servants for Patrick Calhoun, grandson of former Vice President and Senator John C. Calhoun and the developer of Euclid Heights, the first major subdivision in what would become Cleveland Heights. Source: Mildred Calhoun Wick, Living with Love (1986), used by permission of Calhoun Warren Wick. 
the census, 129 of 153 located in the manuscript census ( 84 percent) were either live-in servants or their dependents. Most of the eighty-eight households employing resident servants were single-family homes, although two-fifths of African Americans in the village lived in apartments, most as custodians and their families. Over 80 percent of the eighty-eight households employed one black servant, while 17 percent employed two. One of only two households to employ three was the sixty-five-room Fairmount Boulevard mansion of Kenyon V. Painter, a Cleveland banker and avid big-game hunter who sank millions in a coffee estate and hotel in Arusha, German East Africa (now Tanzania). ${ }^{16}$

By 1930, 389 of 571 African Americans (68 percent) in Cleveland Heights were live-in servants or their dependents. The declining percentage reflects growing custodial opportunities in apartment buildings. Just three households employed three or four black live-in servants. These proportions changed little over the ensuing decade. While the affluent neighborhoods in southwestern Cleveland Heights (west of Lee Road and south of Euclid Heights Boulevard) employed most live-in servants, the geography of domestic labor expanded with the rapid increase of homes in the eastern half of the suburb, with 82 of 389 black live-in servants and dependents ( 21 percent) residing east of Lee. In 1940, 366 of 476 blacks in the city found in the manuscript census were live-in servants or dependents. Even as the overall number declined in the 1930s, many new employers of live-in servants were Jewish residents who had participated in a large-scale exodus of the Jewish community from Glenville to Cleveland Heights, and many went to newer allotments east of South Taylor Road. ${ }^{17}$

Live-in domestic work was the least desirable arrangement because it entailed living under the watchful eye and at the beck and call of their employers. Other challenges included employers' racial fears, accusations of wrongdoing, and outright abuses. The Call \& Post observed that when a white woman was murdered in Cleveland Heights in 1933 "and it was believed that her slayer was a Negro, a number of Negro servants in that section lost their jobs." Some years later, Mr. and Mrs. Albert Levin of 11894 Carlton Road discharged Mr. and Mrs. Elmer Calamese, their black live-in servants, following a dispute. The Levins pressed charges against the Calameses for trespassing three days later despite the absence of unlawful entry, leaving the family, including their seven-year-old daughter, homeless. ${ }^{18}$ The most serious incident was the case of a lumber baron who recruited two young women, Julia Stanford and Petronia Ford, in 1937 from his Alabama mill to work in his Wellington Road home, but his wife subjected them to "peonage conditions," forcing them to work seventeen hours a day for only five dollars a week and forbidding them from sitting down even for meals. Stanford wrote to her uncle in Youngstown for help, and he managed to get the Phillis Wheatley Association to send a social worker, who investigated and helped Stanford find another job. ${ }^{19}$

Many servants also struggled to unite their families as a result of employers' refusal to accept "lodgers," lack of sufficient quarters, or inaccessibility to a spouse's place of work. In 1920, more than two-fifths of married black servants in Cleveland Heights lived apart from their spouses. By 1930 , nearly half dealt with this effective separation. Living apart likely exacerbated some marital problems. As one example, in 1936, Rose Johnson, a housekeeper living at 2685 Fairmount Boulevard, sought to divoree her husband, a Cedar-Central resident whose gambling and drinking problems had forced her to "work as a maid to earn a living." ${ }^{20}$ Families with children were exceedingly rare. In 1920, Kenyon Painter's chauffeur George Bundy lived with his wife and teenage daughter, while John and Mamie Lee served as Painter's butler and maid, respectively. Ten years later, only three such families lived together in the suburb. In one case, seventeen-yearold Opal Owens worked as a cafeteria waitress to supplement her parents' income working in a Coventry Road home. ${ }^{21}$

Even rarer were arrangements that enabled a non-servant "lodger" related to a servant to reside in a white home. The lone exception in 1920 was that of the Rosses. Carrie Lee Ross 
worked as a cook in a Chestnut Hills Drive mansion while her husband Samuel worked as a postal carrier. Ten years later, census takers found only three examples: Fairfax Road servant Sophia Burton's husband Eugene worked as a mechanical engineer; Arthur Miles, a hotel waiter, lived on Overlook Road with his servant wife Beatrice; and Phoebe Blassingame's service allowed her husband Lucius to live with her on Coventry Road while employed as an electrician in a plow factory. In 1940, the picture remained much the same with two non-servant adults. Servants Lucinda and Callie Yarbrough lived in a Coventry Road mansion with their husbands, Tennessee-born brothers Orange and Yerger Yarbrough, who worked as a hotel porter and a book factory worker, respectively. ${ }^{22}$

\section{Building Janitors and Custodians}

Live-in servitude was an unlikely path to independent suburban living. For most, it was little more than a means of earning precious money, and few expected to secure homes outside Cleveland's black sections. In contrast, custodial labor in apartment buildings offered a modicum of autonomy, though most custodians were relegated to basement units that still demanded partial rent and long work hours. Custodial jobs emerged with a boom in "grand apartments" between about 1915 and 1925, especially near streetcar lines in the Euclid Heights allotment. These I- or U-shaped brick buildings were usually two to four stories, contained between sixteen and forty apartments, and carried evocative names like Coronado or Pasadena. ${ }^{23}$

The 1920 census found five black janitors with nine dependents, comprising more than 7 percent of the suburb's black population. In four of five custodian households, women held "janitress" positions, and their husbands worked as a teamster, restaurant cook, postal carrier, and auto painter, respectively. By 1930, 166 African Americans (29 percent) comprised fifty-five households supported at least partially by one custodian. Of twenty-nine male janitor-headed households, the man was the only employed person in twenty-three of them. In only two cases did a janitor's wife work, and both were custodians. However, five male janitors augmented their income with the help of a relative: a stepson who was restaurant busboy, a son-in-law who worked for a florist, a nephew who worked "odd jobs," a brother-in-law who toiled in a foundry, and a blacksmithing father-in-law. In contrast, in every one of the twenty-four households where the wife was the janitor, her husband held an outside job. These included a truck driver, two chauffeurs, a painter, a plasterer, a furniture finisher, three road construction workers, two porters, a messenger, a jewelry packer, two hotel workers, two machinists, two steelworkers, two auto mechanics, and three postal letter carriers. Similarly, in 1940, most male custodians' wives did not work, although the proportion of working wives increased from about one-fifth to about one-third. Likewise, five of six female custodians' husbands worked outside the home, including as a golf course laborer, a road construction worker, two city park laborers, and a painter. ${ }^{24}$

In contrast to the 6 percent decrease in black live-in servants across the $1930 \mathrm{~s}$, the number of black on-site custodial workers and dependents found in the manuscript census plummeted from 166 to 79 for reasons that are unclear. Even in the unlikely event that additional custodians comprised all of the difference between the complete 1940 black population count of 511 and the 476 located in the manuscript census, the decline was still 31 percent. The more minimal net loss of black population in the 1940s, which accounted for only sixty of the 137-person net decline (about 44 percent) from 1930 to 1950, demonstrates that the 1930s (when black custodial population loss was occurring at several times the rate of loss of live-in servants) were the crucial decade of change. The statistics also suggest that the greater drop in black live-in servant population awaited the $1950 \mathrm{~s}$, when the overall black population dropped by about 42 percent to 251 in 1960 , the lowest point since the $1920 \mathrm{~s}^{25}$

Black suburban households secured through janitorial work enjoyed a degree of latitude seldom seen in white-owned homes, in part because many could rely on a spouse or lodger's income 
to lessen the rent burden. Perhaps some could divide their work and non-work time, if not separate them spatially, away from the watchful and insistent presence of their employers. Hours were long and the pay meager, but, to a limited extent, custodians and their families could carve out "places of their own."26

\section{Independent Apartment Renters}

Exceedingly few African Americans secured apartments independently of domestic service. Faded manuscript census pages partially obscure the occupations of the two heads of renter households in 1920 , but one was a laborer and the other held a presumably professional occupation "in private practice." The latter, William Sisce, lived with his wife Gertrude, two sons, a daughter and her husband, and a servant. Sisce's older son Vincent brought additional income to the household as an elevator operator, while his son-in-law Claudio worked as a chauffeur. In 1930, enumerators identified three renter households totaling five residents. By 1940, that number had risen to five households totaling seventeen members, all near either the Coventry Road or Cedar-Fairmount commercial nodes. One black family, who had migrated from Georgia in the 1920 s, rented an auto storage garage at 2652 Hampshire Road with living quarters above at the rear of two lots that interrupted a row of two-family houses. Chauffeur Frank Clayton owned and operated the garage, which probably served the large apartment buildings that surrounded this block. He shared upstairs quarters with his wife Susie and their five children. The Clayton residence was the exception to the rule of basement apartments like those that custodians also occupied. Mae Lee Palmer and her husband August, a WPA laborer, occupied the basement of a four-suiter on Mayfield Road. Shelby Watkins, an interior decorator, rented in the basement of a sixteen-suite building on Glenmont Road with his wife Ida. Edgar and Annette Chapman lived in the basement apartment in the Derbyshire, a four-suiter on Surrey Road. Together the couple made \$1,612 in 1939 with his work as a porter (possibly across the street in the Spanish-Moorishstyle Alcazar Hotel) and her WPA sewing work. ${ }^{27}$

Five buildings to the north of the Chapmans, Everett D. and Mamie Lee and their sons rented the basement in the Attleboro, a four-suiter at 2096 Surrey (see Figure 4). Lee had worked as a stock clerk for a wholesale druggist and as a barber in his hometown of Wheeling, West Virginia, before migrating to Cleveland with his family in $1927 .{ }^{28}$ By 1935 , he became the assistant manager in a U.S. Treasury Department office of eighty-five white employees, enabling a move from Cedar-Central to Glenville. In the late 1930s, he managed finances for the Outhwaite Homes and later worked for the U.S. War Department. After their sons graduated from Glenville High School, the Lees moved to the Attleboro in $1938 .{ }^{29}$ They may have chosen Cleveland Heights because their older son Everett Jr. studied violin at the Cleveland Institute of Music with Joseph Fuchs, who lived a block away in an Art Deco apartment tower. The relationships Everett Jr. forged with Cleveland Orchestra members and his father's ease in white-dominated work settings may have helped the Lees feel more comfortable lifting the ivory curtain. ${ }^{30}$

\section{Pioneer Homebuyers and Homebuilders}

In 1930, the Cleveland-born African American writer Charles W. Chesnutt, late in his long career of writing about the color line, observed that only fifteen families who were "not obviously Negroid" had managed to move into Cleveland Heights, Shaker Heights, and Garfield Heights, along with ten in East Cleveland and six in Euclid. Historian Marian Morton later wrote that "[w] hen African-American entrepreneur Alonzo Wright moved into a home on Hampshire Road in the 1930 s, it was bombed." Her isolated mention of Wright leads directly to a discussion of subsequent bombings in the $1960 \mathrm{~s}$, leaving the impression that Wright was the first and only African American to attempt to buy in Cleveland Heights for decades. The prevailing narrative that 




Figure 4. The Attleboro, 2096 Surrey Road, home of Everett Lee family. Everett Lee, a government worker, his wife Mamie, and their two sons moved from the Glenville neighborhood to this apartment building in the Cedar-Fairmount district of Cleveland Heights in 1938.

Source: Cuyahoga County Building Card Index, Cuyahoga County Archives, Cleveland.

Cleveland Heights lacked a black homeowner presence until the emergence of fair housing activism elides a more complicated and important story. ${ }^{31}$

Wright was actually the third black homeowner in Cleveland Heights. The first preceded him by eight years and spent seventeen years there without documented incident. The second arrived three years before Wright and, despite also suffering a bombing, remained in the suburb more than two decades after Wright left. In fact, at least ten African American individuals or families acquired building lots or houses there between 1923 and 1957. Five suffered bombing or arson attacks and a sixth had her partially built house torn down by angry whites. However, four do not appear to have been attacked. Regardless of their reception by the largely white community, eight black families completed or bought homes in Cleveland Heights. Six of these household heads were physicians. To underscore their success, they were not buying substandard or aging houses. Of the six homeowners who arrived in the 1920s and 1930s, two built new houses and four purchased homes that were between one and eight years old. Although Wright's house was located in the C-rated Coventry area (C60) shaded yellow by Home Owners' Loan Corporation (HOLC) appraisers in the 1936 City Survey, all others were in blue-shaded, B-rated areas (see Figure 5). The two families who followed, in 1949 and 1957, bought much larger houses that were very well-constructed despite being twenty-five and thirty-five years old, respectively, at the time of purchase.

The first black homeowners in Cleveland Heights were Alfred B. and Mayme E. Copes. Alfred's father, Fenderson Copes, was born into slavery in New Bern, North Carolina, and migrated in the 1860 s to Oberlin, Ohio, where he owned a farm. ${ }^{32}$ Born in 1880 , Copes lived in 


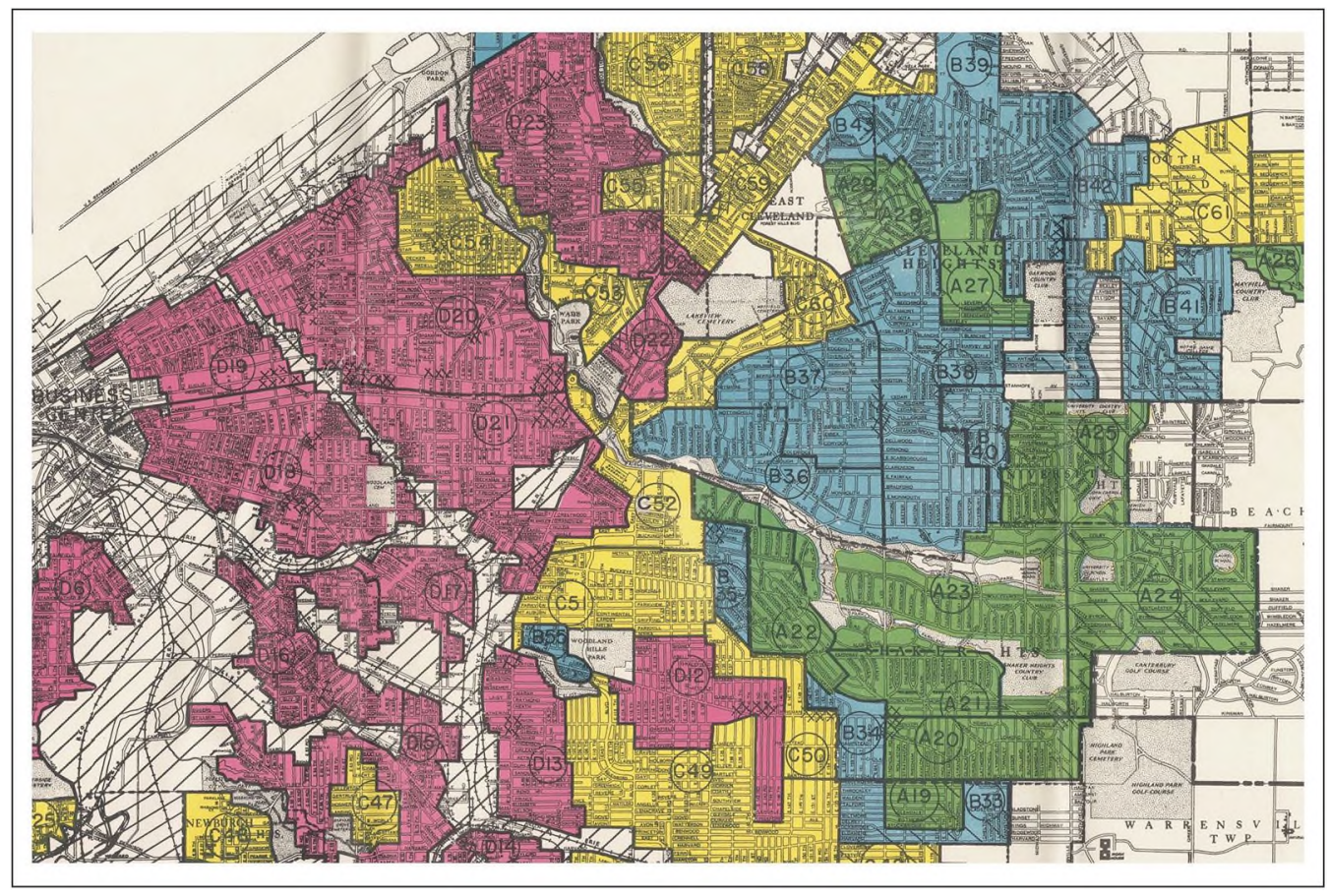

Figure 5. Home Owners' Loan Corporation (HOLC) area grades for Cleveland Heights, 1936. Despite the presence of several black homeowners, the Cleveland Heights neighborhoods they occupied were all designated with HOLC's B or C ratings.

Source: Robert K. Nelson et al., "Mapping Inequality," American Panorama, ed. Robert K. Nelson and Edward L. Ayers, https://dsl.richmond.edu/panorama/redlining/\#loc $=13 / 41.503 /-81.613 \& c i t y=$ cleveland-oh

Oberlin or nearby Lorain until 1915, when he moved to Cleveland and married Mayme Yates, originally from Springfield, Ohio. They lived first in Cedar-Central and then in Union-Miles Park in southeastern Cleveland. ${ }^{33}$ In 1923, the Copeses acquired a lot in the Frisbie-Berwald Company's Shaker Lakes Subdivision. Despite the developer's original ads in 1910 that carried the misleading header, "Shaker Heights, Cleveland's Most Carefully Restricted Residence Suburb," the couple managed to build a home at 2498 Princeton Road without a white intermediary (see Figure 6).$^{34}$ Alfred Copes's appearance did not fit Chesnutt's claim that only those "not obviously Negroid" became suburban homeowners. Perhaps he avoided the obstacle of securing a construction loan because he was an established builder. Before 1923, only four of twenty-five lots on their block were developed, although five others were also built that year. All were on the west side of the street because the Cleveland Heights Village School District purchased the entire east side of that block in 1921 and opened Canterbury School eight years later. Proximity to the school property may have given the Copeses some comfort and protection. The couple lived there without any documented incident for seventeen years until the builder's construction of a home for his sister a few blocks away prompted white backlash, as will be detailed later. ${ }^{35}$

The second African American home acquisition in Cleveland Heights was that of Dr. Robert T. (R. T.) Wise and his wife Lula B. Wise. Born in Mart, Texas, in 1891 to farming parents, R. T. Wise graduated from Meharry Medical College in Nashville in 1918 and moved to Cleveland to start his practice. He married Lula, also from Texas, in 1922, and they lived in the Hough neighborhood (north of Cedar-Central) three decades before blacks began to move there in large numbers. ${ }^{36}$ Their path to homeownership is unclear, but by 1927 they had turned their attention to a 


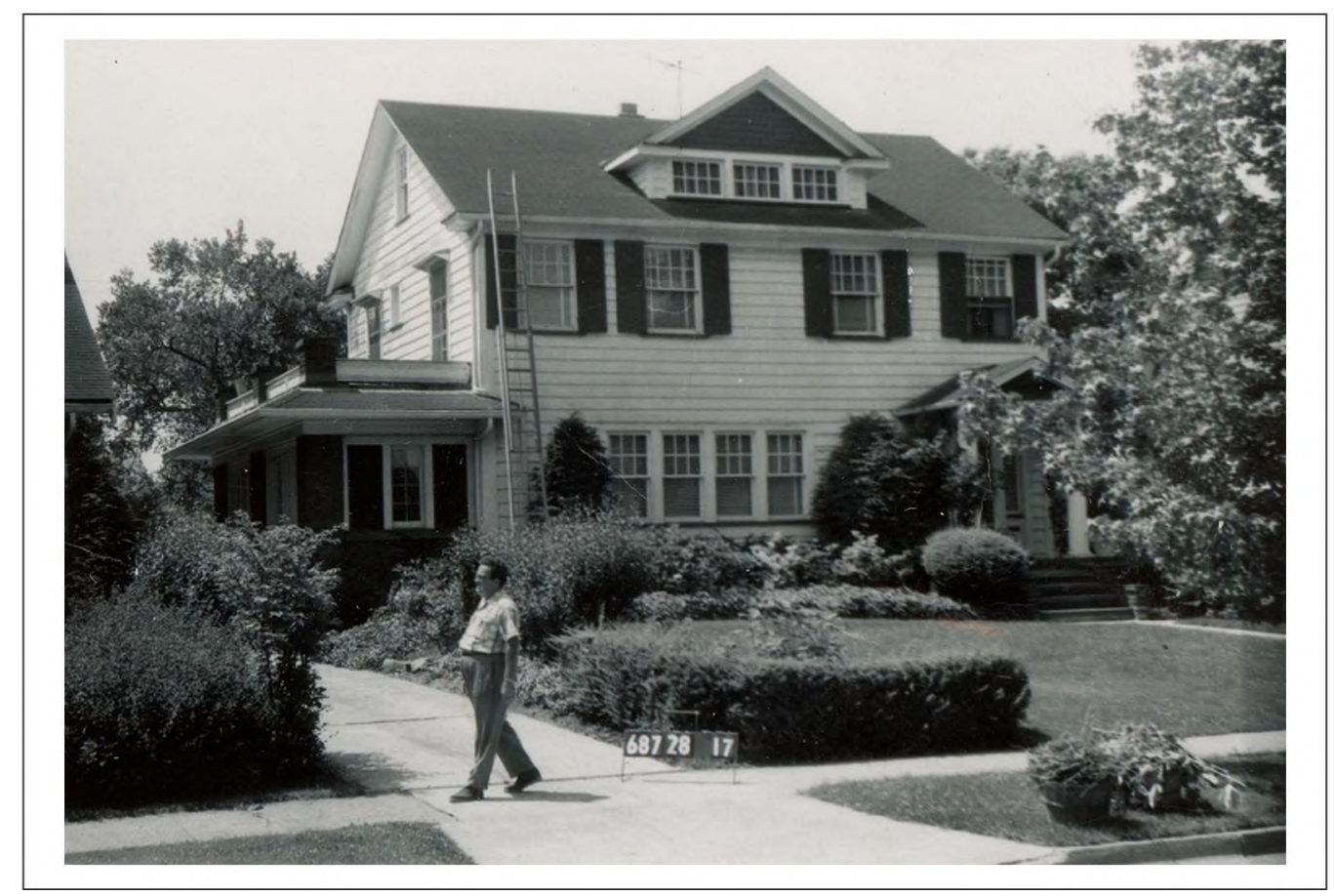

Figure 6. Alfred and Mayme Copes House, 2498 Princeton Road. In 1923, Alfred and Mayme Copes became the first African Americans to own a home in Cleveland Heights.

Source: Cuyahoga County Building Card Index, Cuyahoga County Archives, Cleveland.

brick home on a corner lot at 3075 Washington Boulevard (see Figure 7). The house was originally listed for $\$ 37,000$ in 1925 . Samuel Friedman purchased the house the following spring, soon relisted it, and when it failed to move, reduced the price "For Immediate Sale." ${ }^{37}$ In a flurry of transfers, the property changed hands five times between July 1927 and April 1928. The Wises worked through a white intermediary, Saul Greenberg, to whom Friedman conveyed the house. Greenberg transferred it to Lula Wise, who then deeded the house to Leon A. Greenberg, who may have been Saul's son. He transferred the title to Richard Baldwin, who in turn handed it back to Wise for good. ${ }^{38}$ The Wises may have hoped to keep white neighbors guessing as to the home's true owner.

The couple may have spent months or longer free from threats, possibly by delaying their move, minimizing time outdoors, and planning their arrivals and departures with extra care. An oral history interview conducted with Stanley Adelstein, whose family lived at 3052 Washington, suggests that the Wises delayed moving in, taking a long view in their pursuit of upward mobility. But ultimately they could not stave off white anger. Adelstein recalled that the Wises moved to the house in either 1932 or 1933 and that his neighbors "put together enough money and they had somebody to plant an explosive." After the bomb went off, Adelstein remembered, "we rushed out in the street, and the black family consisted of a physician and his wife. And the wife kept saying to the police, I don't know why this happened." ${ }^{39}$ Despite the bombing, the Wises stayed. The HOLC appraiser who prepared the description for the B-rated (blue-shaded) area B37 in 1936 noted tersely, "One colored family is located in this area at the corner of Washington Blvd. and Cottage Grove." In fact, seventy B37 households had African American residents, but the appraiser, like most whites, distinguished desirable black domestic providers from undesirable black homeowners. ${ }^{40}$ Lula Wise died in 1954 , and her husband remained in their home until his 


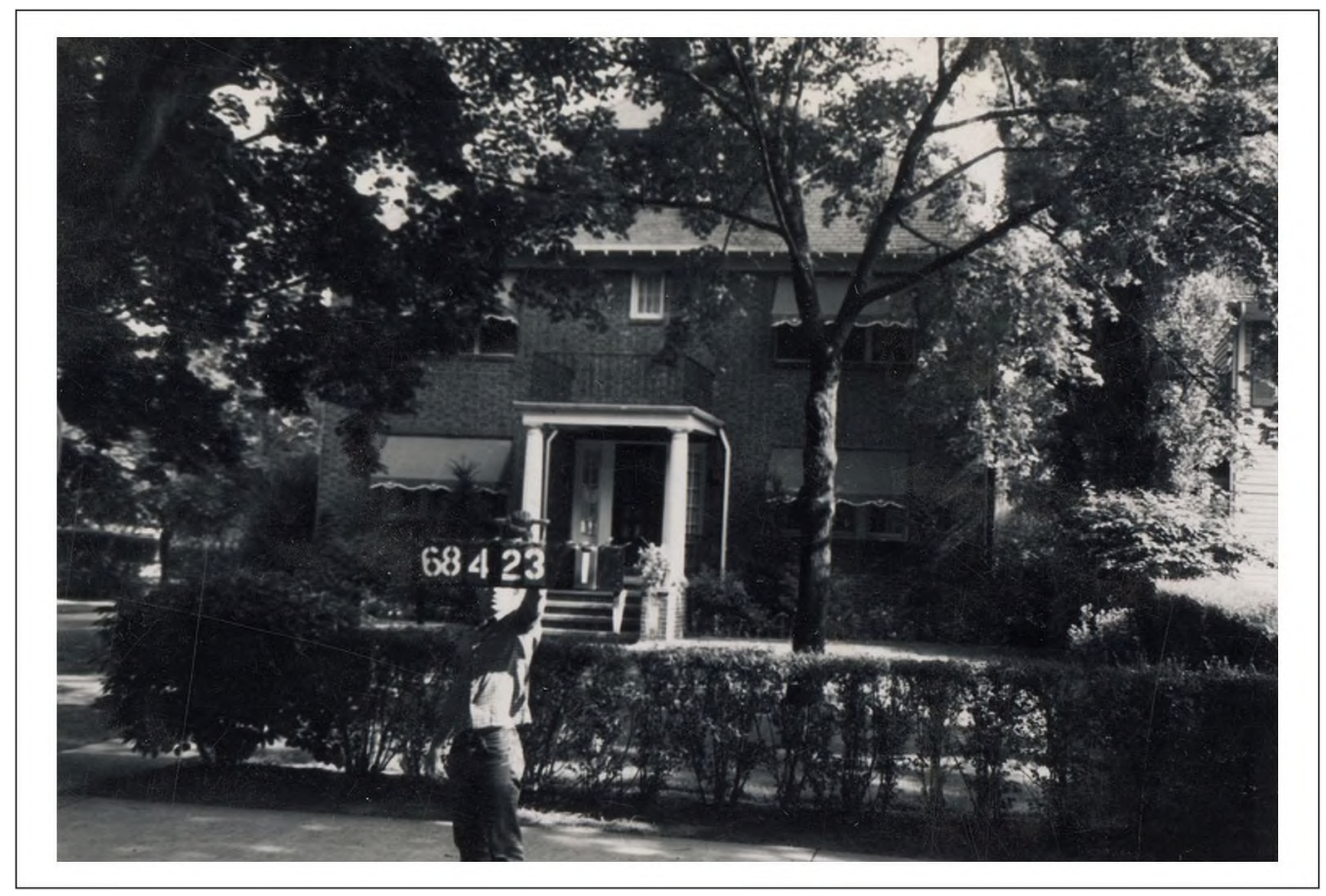

Figure 7. R. T. and Lula Wise House, 3075 Washington Boulevard. Dr. R. T. and Lula Wise acquired this house in the late 1920s and suffered a bombing attack in the early 1930s, after which they stayed for many years without further known incidents.

Source: Cuyahoga County Building Card Index, Cuyahoga County Archives, Cleveland.

death in 1968, after which his second wife Esther stayed another four years, making this house one of four black-owned properties in the city at a time that many more African Americans were beginning to buy homes there. ${ }^{41}$

About a year after the Wises gained clear title to their home, newlyweds Alonzo G. and Henrietta C. Wright began the arduous process of buying a house eight blocks to the north. ${ }^{42}$ Wright was born in 1898 in Fayetteville, Tennessee, and raised in a one-room shack by his widowed laundress mother after his father, a lumber bearer in a sawmill, died when he was little. He moved with his mother and two brothers to Cleveland in 1912. Wright's mother found work ironing laundry and he was employed in a foundry by $1920 .{ }^{43}$ Later, when Wright was working as a downtown garage attendant, he met the former Standard Oil of Ohio (Sohio) president, who offered him a job. Soon Wright was turning a money-losing service station into a national success story that revolved around his innovation of offering free windshield washing, which pleased customers and prompted many to make purchases in the time the small job took. His fortunes rising, Wright met and married Henrietta Cheeks, a schoolteacher from Abington, Virginia, in 1929, and they lived on Westchester Avenue in Glenville. ${ }^{44}$

Although Wright later became one of Ohio's first black millionaires, he was still early in his financial ascent that came as he went from operating one Sohio station to leasing eleven by the late 1930s and then investing in real estate and operating hotels. Eventually Wright would be accepted as the first African American member of the Cleveland Chamber of Commerce and be the first black developer of a Cleveland skyscraper, but when he and Henrietta were planning to become parents, they were not yet sufficiently affluent or confident to buy a large Heights home that would have called more attention to themselves. ${ }^{45}$ 


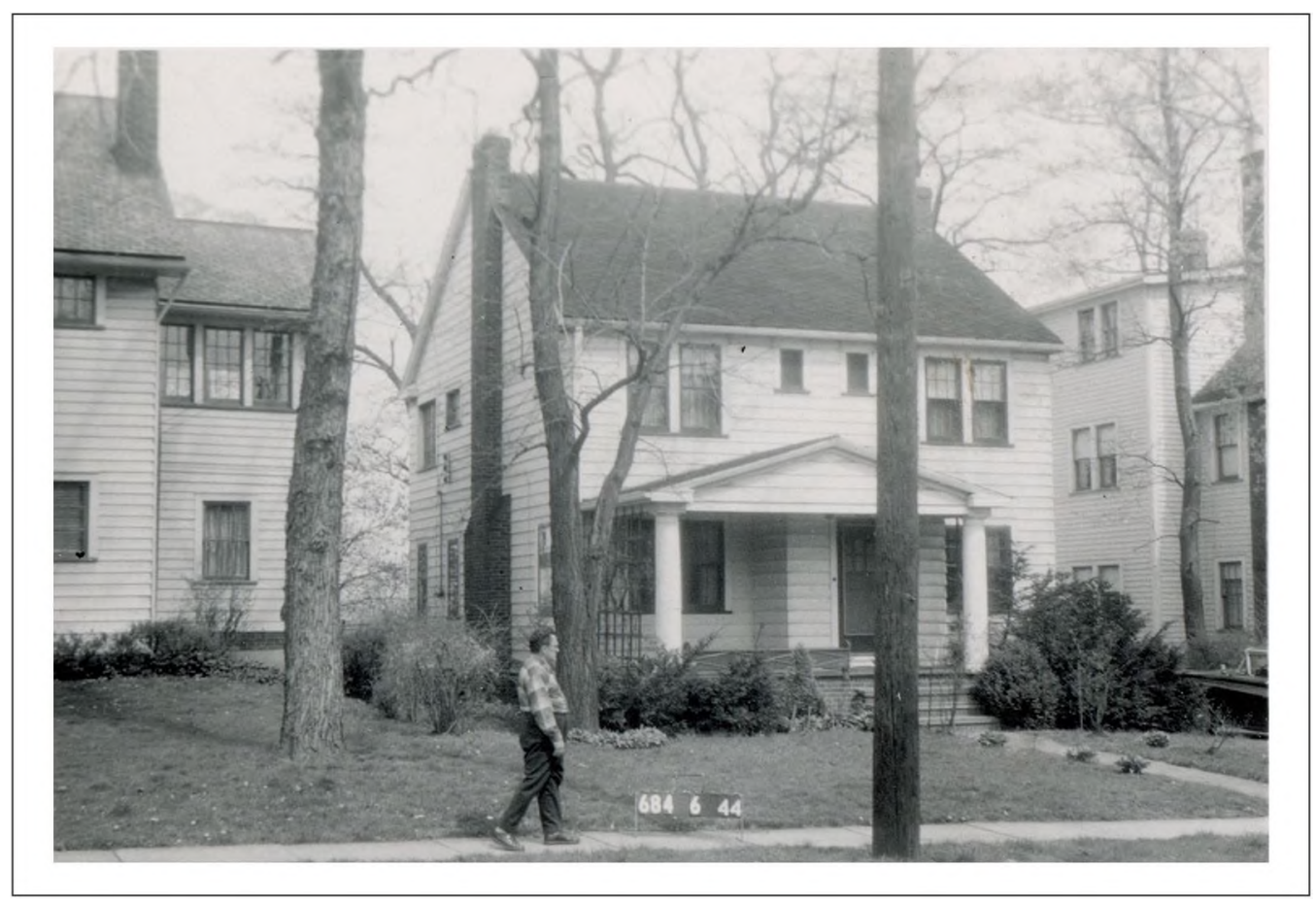

Figure 8. Alonzo and Henrietta Wright House, 2985 Hampshire Road. Alonzo and Henrietta Wright secured the third black-owned household in $193 \mid$ and endured a bombing attack. A gas station franchisee, Wright went on to become a major real estate investor and Cleveland's first black millionaire.

Source: Cuyahoga County Building Card Index, Cuyahoga County Archives, Cleveland.

Accordingly, in June 1929, the Wrights orchestrated a clandestine purchase of an unassuming house. Charles and Ethel Obey agreed to serve as intermediaries to buy Hermina Keller's 2985 Hampshire Road home and then transfer it to the Wrights (see Figure 8). Months later, Ethel Obey transferred the Cleveland Heights property to Wright's wife. That the transfer was made to "Henrietta B. Cheeks" may have been an oversight, but perhaps it was a means of hiding a connection to Wright, who was becoming well-known. Importantly, Ethel's husband did not relinquish interest in the title until May 1931, and the Wrights told the 1930 census enumerator that they rented the house for $\$ 75$ a month. Whether this was another way of obscuring ownership is unclear, but Obey's transfer of his interest in the property concluded a two-year process that formed the backdrop for the bombing of the couple's home soon after. ${ }^{46}$ Like the Wises, the Wrights were determined to stay. Their son Gordon attended school in the suburban system through his junior year at Heights High, when they moved in 1947 to a Geauga County farm, and he would go on to be one of the first to integrate the nationally known Ludlow section of Shaker Heights a decade later. ${ }^{47}$ Wright's perseverance complicates the idea that violence prevented blacks from overcoming the challenges of seeking homes in Cleveland Heights.

Two more physicians occupied new homes in the early 1930s, both on Meadowbrook Boulevard in Cedarbrook Allotment No. 4 in southeastern Cleveland Heights. Dr. Armen G. Evans and his wife Louise Canneville Evans had bought an empty lot at 3507 Meadowbrook in 1925, a couple of years before any houses were built on the street, while Dr. Hardie F. Harris and his wife Endor A. Harris purchased a three-year-old Tudor Revival at 3544 Meadowbrook (see Figures 9 and 10 ) ${ }^{48}$ The Evanses waited to build for six years, possibly to allow time to watch 




Figure 9. Hardie and Endor Harris House, 3544 Meadowbrook Road. Dr. Hardie and Endor Harris moved to Cleveland in 1924 and bought this house in Cleveland Heights near the University Heights border in 1930, but they only stayed five years before moving back to Cleveland. Source: Cuyahoga County Building Card Index, Cuyahoga County Archives, Cleveland.

how the subdivision developed. In 1931, they transferred their deed to Clarence Mack, who obtained a permit from the city and built the house, which he transferred to Cornelia F. Nickens, Dr. Evans's mother. ${ }^{49}$ A North Carolina native, she had married a railway porter and moved to Cleveland's Cedar-Central before Armen was born in 1895. After her husband died when Armen was still a boy, Cornelia married James K. Nickens, a drug manufacturer. ${ }^{50}$ Armen earned a WRU medical degree in 1920 and was a pediatrician at Rainbow Children's and St. Luke's Hospitals. ${ }^{51}$ Nickens, who continued to live in Cedar-Central, held title to the Meadowbrook home, enabling the Evanses to claim renter status until they acquired the deed for good in 1944.

The Harrises' and Evanses' paths converged in the time they lived on Meadowbrook in the 1930 s, but from there they diverged. Hardie Harris, who was born in Wetumpka, Alabama, in 1886, earned his medical degree from Meharry in 1905, and practiced in Anniston, Alabama, where he married Endor, a Mississippi native. The couple moved to Buffalo, New York, before resettling in Cedar-Central in 1924. They moved to Cleveland Heights in 1930, working through intermediaries to buy their house from Louis and Ruth Siegel. Details of the Harrises' suburban experience are elusive. Their return to Cedar-Central after only five years and subsequent purchase of a home in Mt. Pleasant suggest that, at the least, living in Cleveland Heights could be socially isolating. ${ }^{52}$ Yet, isolation could also protect. Between 1932 and 1945, only five additional houses were erected on the fifty-three lots on Meadowbrook between South Taylor Road and the University Heights border. With few neighbors to note their presence, the Evanses seem to have avoided outright hostility, and they sent their daughters Gwendolyn and Barbara Ann through the public schools, where they both graduated from Heights High in the mid-1940s. The Evanses lived on Meadowbrook until his death in 1975 and hers in 1982. ${ }^{53}$ 




Figure 10. Armen and Louise Evans House, 3507 Meadowbrook Road. Dr. Armen and Louise Evans built this house in 1932, keeping the home's title first in a contractor's name and then in Dr. Evans's mother's name until 1944. They represented themselves as renters in the twelve-year interim. Source: Cuyahoga County Building Card Index, Cuyahoga County Archives, Cleveland.

Seven years passed between the Evanses' arrival and the next black homeowners, Dr. Luther O. Baumgardner and his wife Myrtle. Baumgardner was born in Wedgefield, South Carolina, in 1896 and grew up in Clarendon County, which would later become the location of one of five cases joined together in Brown v. Board of Education. He attended Howard University and started his medical practice in Columbia, South Carolina, in 1921. Three years later he migrated to Cleveland, where he married Myrtle L. Robinson, who had grown up on a dead-end alley in eastern Hough until her father went to work for General Electric's Nela Park lamp plant and moved the family to East Cleveland. J. C. Robinson had a light enough complexion that, as the Great Migration brought a hardening of the color line, he chose to change his race classification from "Black" to "White" between the 1910 and 1920 censuses. When Luther and Myrtle wed, they also listed themselves as white in the 1930 census. ${ }^{54}$

In 1937, the Baumgardners learned of a house listing at 1504 Wilmar Road, one block south of Mayfield Road, the major thoroughfare that ran from University Circle through Little Italy and Cleveland Heights and eastward through a string of interwar suburbs (see Figure 11). Despite claiming whiteness to the census taker seven years earlier, they followed the well-worn path of enlisting white intermediaries, C. J. and Sarah Condon, who acquired the house from Sol and Theresa Burg and passed the deed to the Baumgardners three weeks later. Remaining cautious, the couple delayed moving in until August 22, 1938, after their second daughter Jane was born. ${ }^{55}$ Five nights later, the Baumgardners' and their neighbors' windows shattered in near unison as Dr. Baumgardner was tucking Jane into bed. A stick of dynamite had blown a jagged crater in the Baumgardners' front lawn. When asked by a Plain Dealer reporter to comment, Mayor Frank Cain demurred, saying he would confer with the police department the next morning. The Call \& 


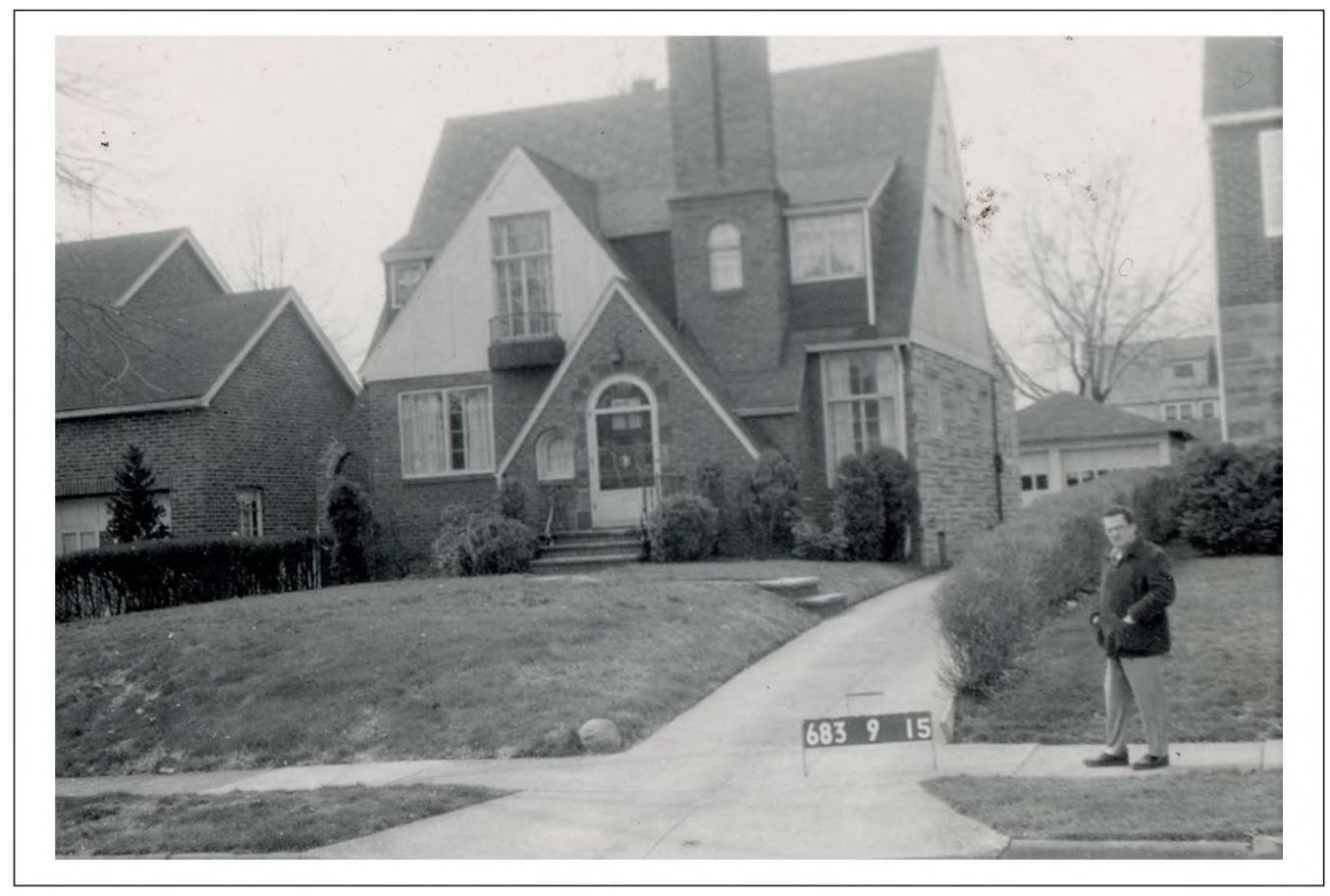

Figure I I. Luther and Myrtle Baumgardner House, I504 Wilmar Road. Dr. Luther and Myrtle Baumgardner moved from East Cleveland to Cleveland Heights in 1938. After only five nights in their home, the house was bombed, but the Baumgardners remained until his death in 1976.

Source: Cuyahoga County Building Card Index, Cuyahoga County Archives, Cleveland.

Post responded caustically, "We hear much about law and order in these residential suburbs that surround Cleveland. Yet, at times, they appear just as full of lawless elements as the City of Cleveland which they like to thumb their noses at." The black weekly implored Cain to protect all citizens regardless of race. About a week later, the police reported finding a note warning that if the Baumgardners moved in they would be "blown to bits." 56

The attack, like most against black homeowners, was never solved. Unlike the Evanses, the Baumgardners did not leapfrog most white suburban development but instead bought on a street where eight of twenty-four lots already had houses, meaning that the culprits were quite possibly grudging neighbors rather than "Ku Kluxers," as the Cleveland Gazette called them. ${ }^{57}$ Determined to stay in their suburban home, the Baumgardners became longstanding Heights citizens, sending their daughters Gretchen and Jane through the Heights public schools and remaining on Wilmar Road until Dr. Baumgardner died in 1976..$^{58}$

The late 1930s were a critical time in the trajectory of black access to housing in Cleveland Heights. After the Baumgardners refused to be forced out, a pair of more serious incidents unfolded in 1939 when African Americans sought to build in the Cedarbrook neighborhood where the Evanses still resided (and several blocks north of Alfred and Mayme Copes's home). The purchasers were related to each other and to the Copeses, and it is likely that the proximity of the lots to the Copes and Evans homes influenced their decisions to locate in Cleveland Heights. In 1936, Effie Dixon, Mayme Copes's sister, bought a lot at 3552 Northcliffe Road, one block north of Meadowbrook, and two years later Effie Baxter, Alfred Copes's widowed sister, did the same on Meadowbrook at Queenston Road. If these newcomers succeeded in building, the small subdivision would see its black households triple in number. It seems that whites were 
determined to hold the line based on what followed. The details of the Dixons' efforts are unusually well-documented thanks to a court battle that ensued. ${ }^{59}$

Effie Dixon, the daughter of a drayman, was born Effie Yates in 1889 in Springfield and grew up in Cleveland on Blaine Avenue in eastern Hough. In 1924, she married Edgar N. Dixon, who was born in 1902 in Buffalo and migrated to Cleveland in 1908. The couple rented an apartment in Cedar-Central, and Edgar earned a degree in 1928 from the John Marshall Law School while working as a clerk in the law firm of McKeehan, Merrick, Arter \& Stewart. In about 1932, the couple appear to have moved in with Mrs. Dixon's sister and her husband (the Copeses) on Princeton Road. ${ }^{60}$ After the Dixons bought their lot, Second Federal Savings and Loan Association sent them a letter inviting them to apply for a construction loan. When the Dixons appeared at the bank, the officer they met was thunderstruck and embarrassed. Apologizing profusely, he told them it was "the policy of the bank not to loan money to Negroes under any circumstances." Dixon asked Homer McKeehan for help in getting a loan, and McKeehan called the head of Central National Bank to ask him to support Dixon. The Dixons left a copy of their house plan at the bank, but in less than twenty-four hours they received the plans in the mail with a perfunctory rejection. ${ }^{61}$

Two years passed, during which the Dixons grew increasingly despondent. In November 1938, Mrs. Dixon tried to run ads in Cleveland's three daily newspapers to sell their lot with "no objection to colored." The Plain Dealer and Cleveland Press "flatly refused," while the Cleveland News accepted the ad and then quietly excised the reference to race. To the Dixons' dismay, the ads prompted only "numerous phone calls from neighbors protesting the sale of property to Negroes." Running out of options, the Dixons took a different path, agreeing to speak to S. J. Silverman, a Jewish contractor whom a black real estate broker recommended. Silverman told the Dixons he would handle the application through his business, Reliable Improvement Company. The Dixons contracted with Reliable in January 1939 to build their home for $\$ 6,450$, paying $\$ 1,000$ down. On Silverman's instructions, Effie Dixon executed a quit claim deed to Joseph J. Atto, a white associate of Silverman, who took out a loan in his own name at Second Federal with the plan to transfer the title back to the Dixons once the home was completed. Silverman never told Atto that the Dixons were black. During construction, the Dixons "contented themselves with an occasional drive" by the house, never daring to stop. One day in late May, they finally decided to go inside and were spotted by white neighbors. Edgar Dixon returned a second time and learned from his contractor that the next-door neighbor had quizzed him about the owner's identity and said the neighborhood would never accept black buyers (see Figure 12). ${ }^{62}$

In June, the situation worsened. Over the course of two weeks, some person or persons entered the house repeatedly, flooding it on June 12 and starting a fire eleven days later that left "smokestreaked walls." On the afternoon of June 26, the Dixons visited the house. After ten minutes, they returned to the street to find themselves surrounded by contemptuous white neighbors. According to Effie Dixon's account, a woman standing in a yard two houses away remarked, "The nerve of those n----rs wanting to move in this white neighborhood." When the couple turned to face her, the woman shouted, "What are you looking at?" to which Dixon fired back the same question, prompting the woman to sneer, "I am looking at a bunch of n----rs." That night, "the floors were sprinkled with gasoline, [and] a rock wrapped with newspapers and rags saturated with gasoline was ignited and tossed through the milk chute[,] starting a fire and explosion" that blew out the front door, shattered windows, and caused interior fire damage. ${ }^{63}$

Meanwhile, the Cleveland Heights city solicitor, bowing to pressure from aggrieved white residents, urged Second Federal to ask Dixon to give up title to the property. Whether to shore up the color line or merely to safeguard its investment, as it would claim in court, Second Federal allegedly coerced Atto to surrender the deed. The bank also declined to refund the money the Dixons had invested in the lot, suggesting instead that it would complete the house, offer it for 


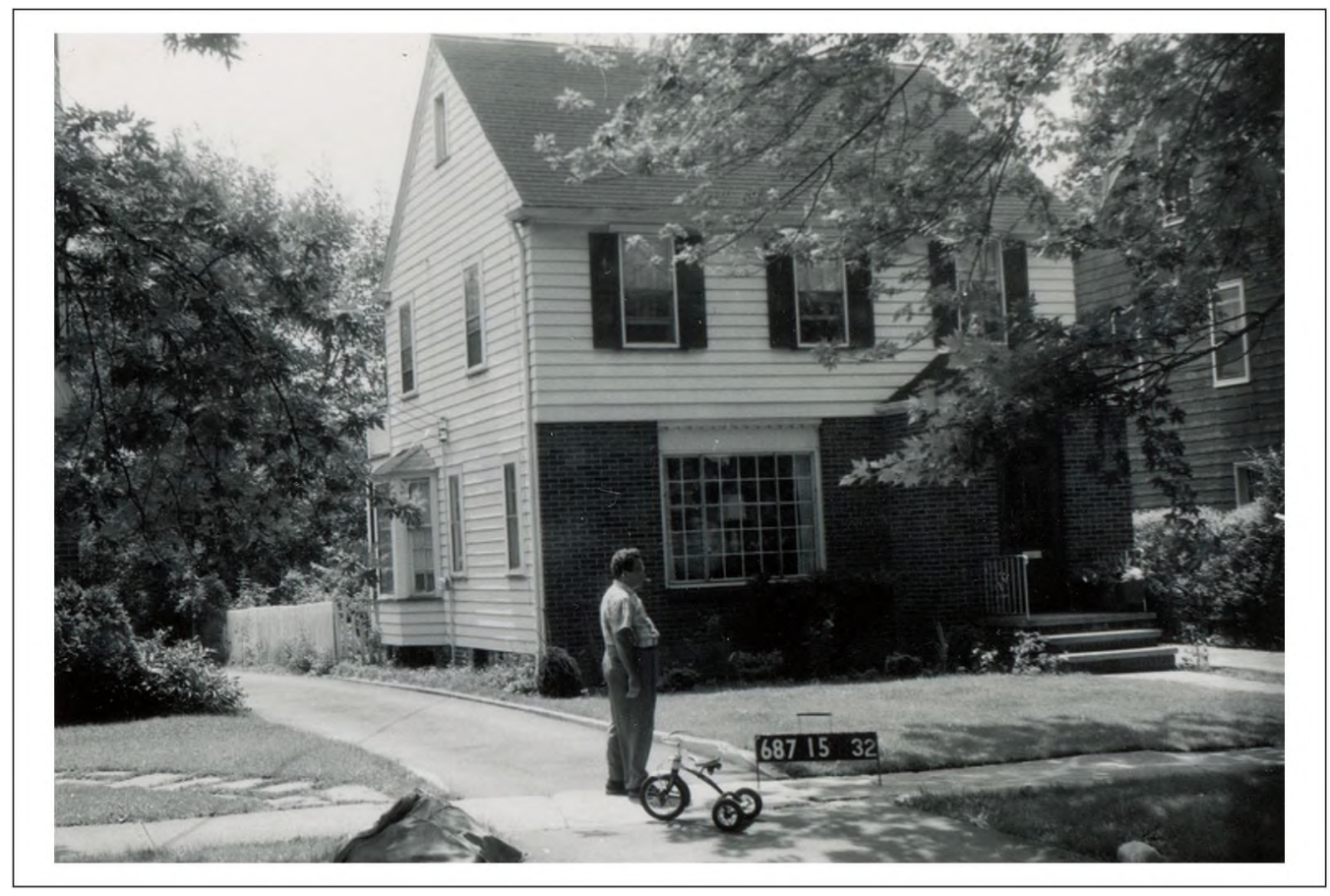

Figure 12. Edgar and Edith Dixon House, 3552 Northcliffe Road. Edgar and Effie Dixon built this house in 1939 after securing a loan through a white intermediary. When their identity was discovered, they faced repeated attacks to their unfinished house, and Edgar Dixon's employer fired him. The savings and loan company that held the mortgage sued the Dixons, forcing them to forfeit it and buy a home in Cleveland's Glenville neighborhood instead.

Source: Cuyahoga County Building Card Index, Cuyahoga County Archives, Cleveland.

sale, and give the Dixons any balance remaining after recovering its own investment. The Dixons refused. As a result, members of his law firm upbraided Dixon for trying to buy a home in an all-white area and said if he weren't so well-regarded, they would fire him at once. Instead, they offered, if Dixon would accept Second Federal's offer, he could keep his job. He refused and was discharged. ${ }^{64}$

One of the firm's lawyers, Keith Lawrence, formerly the Speaker of the Ohio House of Representatives, turned out to be working behind the scenes as a counsel to Second Federal, which decided to foreclose the mortgage and seek a judgment against Joseph Atto and the Dixons for the damage to the property. The bank bullied Atto into handing over the title to Lawrence, who agreed to serve as trustee and be named a defendant in the case even as he was advising Second Federal. Civil rights attorneys Clayborne George and Chester Gillespie represented the Dixons pro bono because they hoped to challenge the constitutionality of longstanding tacit agreements by Cleveland banks not to loan to blacks for suburban homes. ${ }^{65}$

As Second Federal v. Atto et al. lumbered toward a hearing in the Cuyahoga County Court of Common Pleas, Lawrence became a vociferous advocate for Second Federal. The Dixons filed a counterclaim against the plaintiff and Reliable Improvement. They charged that Second Federal, having discovered the Dixons' subterfuge, took their property and then attempted to "give legal color to its act of confiscation," thereby violating their constitutional and civil rights. They sought a $\$ 22,975$ judgment against Second Federal and Reliable to remedy the loss of Dixon's job, forfeiture of the lot, and loss of two payments to Reliable.$^{66}$ Lawrence drafted several replies for Second Federal in which the plaintiff rejected the counterclaim of racial discrimination and 
called it an unwarranted misjoinder because Second Federal was not a party to any contract with the Dixons. The most damning reply came in November: "It was," Lawrence wrote, "the plaintiff's misfortune, but not its fault that the Dixon's course of conduct in having a dummy take title, get a loan, and construct a house, resulted in the plaintiff's security being impaired by flooding, fire and explosion." Second Federal was effectively reinforcing its own subterfuge against that employed by Dixons. ${ }^{67}$ By involving Atto, the Dixons initially benefited from his whiteness but ultimately provoked white sabotage and foreclosure proceedings that now exposed the Dixons to loss without recourse.

When the case came to trial in February 1940, Lawrence was there to goad Judge Walter J. McMahon into overruling the Dixons' defenders' efforts to call out racial discrimination. McMahon carefully steered around the shoals of bigotry and focused on Second Federal's losses rather than the more grievous cascade of misfortune that its refusal to loan to the Dixons had precipitated. Squashing any hopes of challenging discriminatory practices that made white intermediaries necessary conduits for black access to better housing, McMahon ruled that Atto was in default and that Effie Dixon, as the effective owner, must pay all amounts owed plus court costs or face foreclosure and sheriff's sale of the damaged property. After a motion for a new trial was rejected, the Dixons withdrew their appeal, forfeited their dream home, and retreated to a house they bought on Pasadena Avenue in the "surrogate suburb" of Glenville. ${ }^{68}$

Edgar and Effie Dixon's dream of becoming suburban homeowners had yet to become a nightmare when Effie's brother-in-law Alfred Copes was becoming embroiled in another controversy a block to the west. In 1938, Copes's sister Effie Baxter had bought a Cedarbrook lot at 3481 Meadowbrook, six houses west of the Evanses' home. The conspicuous corner lot drew white neighbors' ire when Copes began constructing Baxter's house in 1939. This anger doubtless magnified the vitriolic reaction to Dixon's concurrent attempt to lift the ivory curtain. In March, as Atto was obtaining a permit to build the Dixons' house, whites "condemned" the Baxter house and presumably warned Copes to halt construction. From there it is possible to recreate only a rough picture of events. The Call \& Post showed a pair of photos of the partially built Baxter house and the boarded-up Dixon house in June, labeling them "symbols of race prejudice," but otherwise failed to connect the incidents. Sometime in spring 1940, possibly after attempts to resume construction, irate whites tore down the incomplete house, precipitating another court case. In what was hardly a coincidence, Alfred and Mayme Copes abandoned their Princeton Road home after seventeen years to rent in Mt. Pleasant. In Effie Baxter v. City of Cleveland Heights et al., a case heard by the U.S. District Court, Baxter alleged that city manager Harry H. Canfield and building inspector George D. Williams, along with a private citizen, had conspired to destroy her property. Baxter sought $\$ 30,000$ in damages, but Judge Emerich B. Freed ruled in the city's favor in November 1941. Baxter refused the $\$ 600$ settlement offered her, intending to appeal, but instead sold her lot. Then Baxter bought another house from the prominent black mortician J. Walter Wills Sr. at 10607 Grantwood Avenue in Glenville in 1944 and deeded it to Alfred and Mayme Copes, who moved there from Mt. Pleasant. Thus, on the eve of World War II, Cedarbrook remained almost totally white, with the exceptions of the light-complexioned Evans family and two black maids in other homes. ${ }^{69}$

The 1930s had held a faint promise of a new direction for African American suburban homeseekers but instead ended in setbacks. It was nearly ten years before the next known black family, the Wallaces, attempted to buy in Cleveland Heights. Jesse Etta (J. E.) Wallace, born in 1890 in Calvert, Texas, earned a medical degree from Meharry Medical College and began his practice in Cleburne, Texas, where he met his future wife Lorena Phillips, a schoolteacher. The couple moved to Cleveland in the 1920s and bought a home on Grantwood Avenue where they spent the next two decades. In 1937, the Wallaces also entered the grocery business, starting Cleveland's first black-owned supermarket with two Cedar-Central locations. In 1945, Lorena's younger brother Hiawatha Phillips and his wife Marell moved to Cleveland for Hiawatha to manage the 


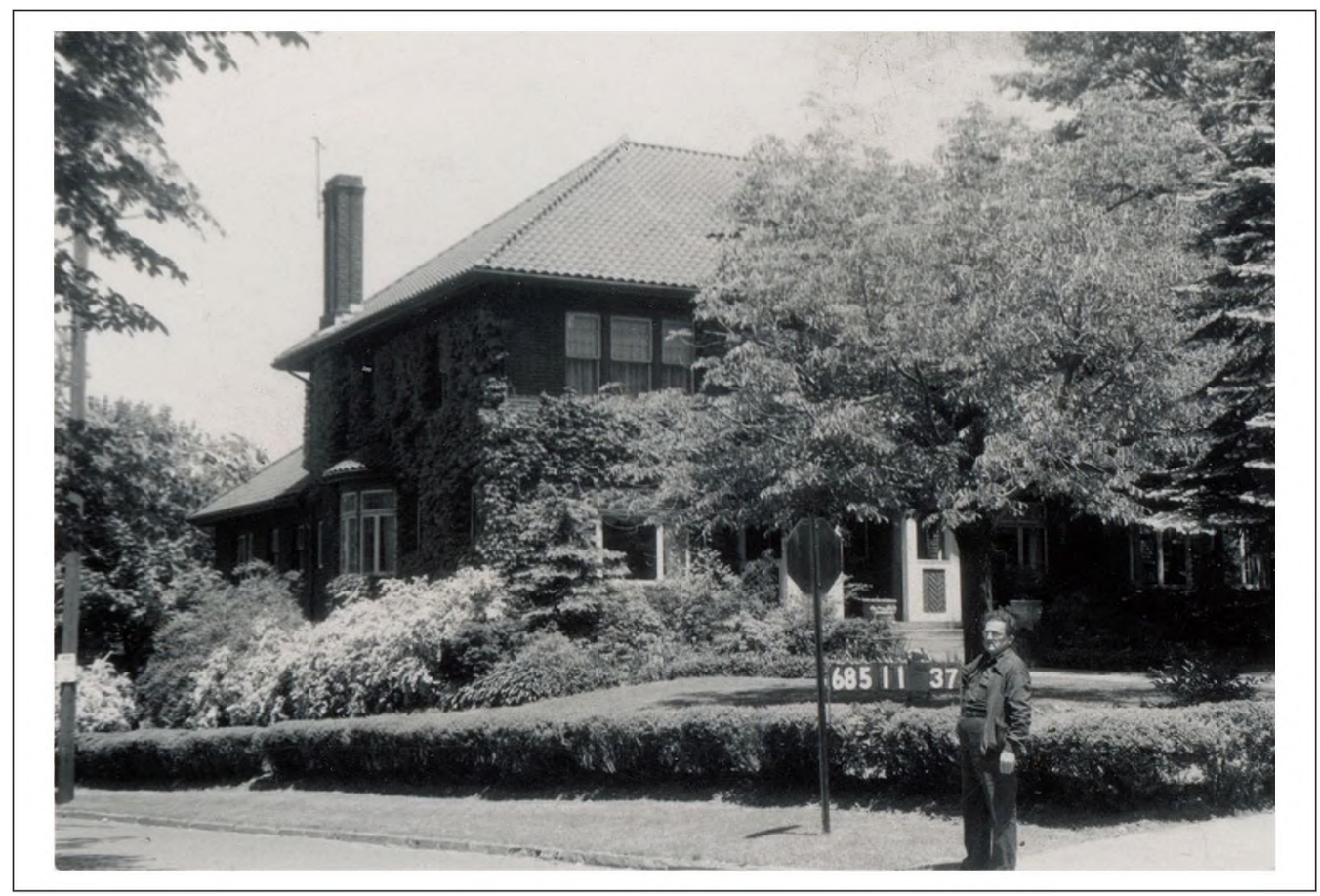

Figure 13. J. E. and Lorena Wallace House, 2737 Edgehill Road. Dr. Jesse and Lorena Wallace, both originally from Texas, bought this Euclid Heights mansion through an intermediary in 1949 and kept it without documented incidents until Lorena's death in 1981.

Source: Cuyahoga County Building Card Index, Cuyahoga County Archives, Cleveland.

supermarkets. In 1949, with the help of a white intermediary, J. E. and Lorena Wallace acquired the 4,600-square-foot, fifteen-room, tile-roofed brick mansion at 2737 Edgehill Road from Samuel and Katie Vinocur. The Wallaces shared the mansion with her brother and sister-in-law and other relatives from Texas (see Figure 13). ${ }^{70}$

Dr. Wallace lived there without known incident until his death in 1969, and Lorena stayed until she also died in $1981 .{ }^{71}$ One may only guess why. Perhaps the brick alley, Mornington Lane, which sloped past the Wallaces' side driveway down to Euclid Heights Boulevard, permitted the family to make their comings and goings as invisible as possible. Or they may have benefited from the fact that no blacks had apparently attempted to buy in Cleveland Heights for a decade. Furthermore, they were able to buy in the midst of some of the suburb's largest estates, where neighbors may have felt less threatened or were simply reluctant to compound negative attention to their street by taking violent action. Whatever the reason, their experience, like that of the Copes and Evans families, demonstrates that it was possible, if rare, for African Americans to buy homes without incident in Cleveland Heights before the 1960s.

The last of the black homeowning families who arrived before 1960 was that of Dr. Emerald B. (E. B.) Spencer, an Alabama native, and his wife Marie C. Spencer, originally from Urbana, Ohio. Born in 1895, E. B. Spencer earned a medical degree from Howard University in 1925 and opened his practice in Cleveland the next year. ${ }^{72}$ By 1930 , the Spencers lived in a Mt. Pleasant apartment before purchasing their first home at 10606 Grantwood Avenue in 1938. Although Dr. Spencer held an M.D. and his wife was a college graduate, their color necessitated the help of a white intermediary to buy on a street where grade school and high school educations were the norm. ${ }^{73}$ Six years after their move, Alfred and Mayme Copes moved across the street. It seems 


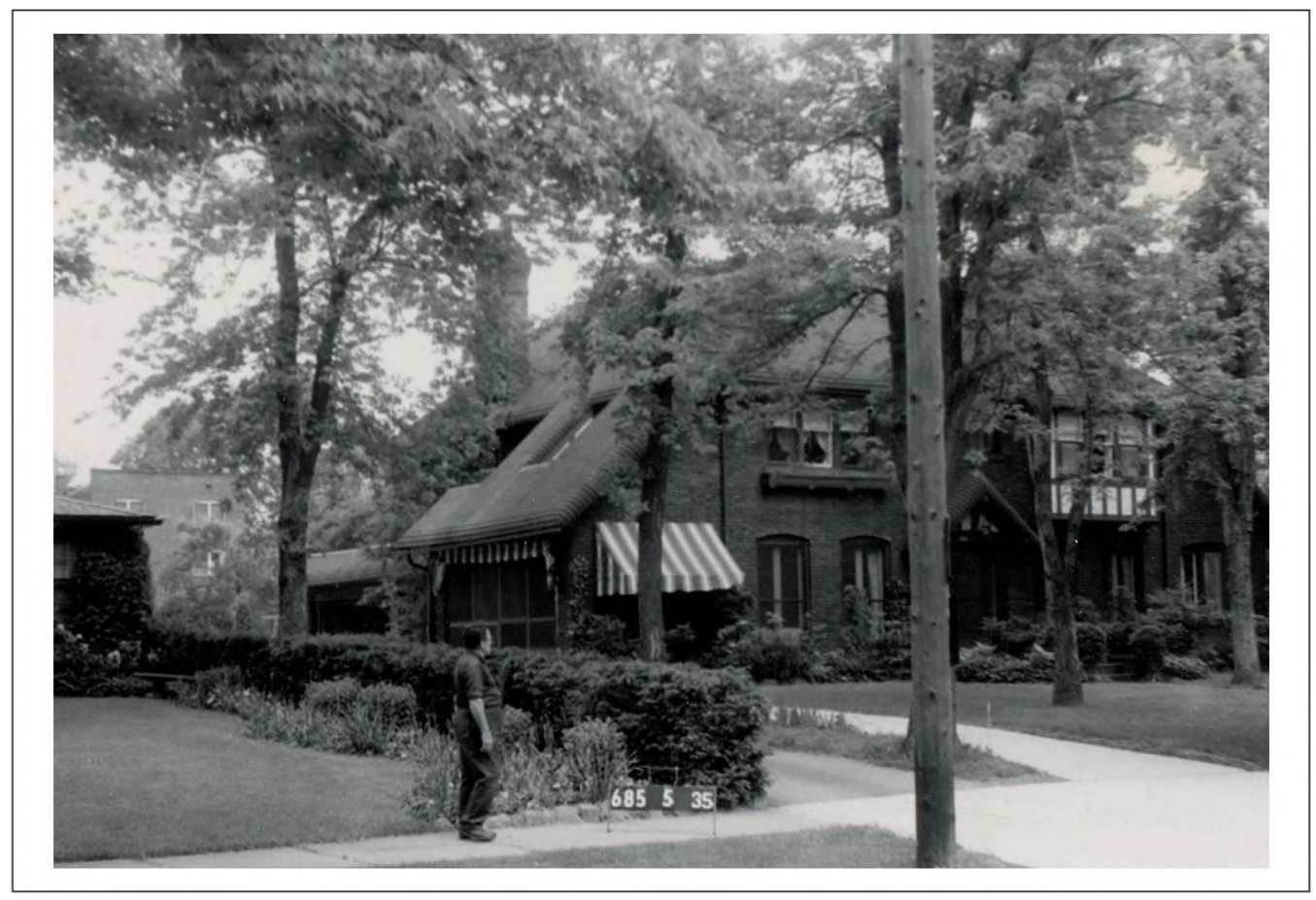

Figure 14. E. B. and Marie Spencer House, 2473 Edgehill Road. Dr. E. B. and Marie Spencer bought this large home in the Euclid Heights allotment in 1957 through a white intermediary, repeating the same tactic they had used nineteen years earlier to buy their previous house in Glenville. In Cleveland Heights, they faced repeated assaults on their property, yet they eventually found acceptance as the suburb became more progressive.

Source: Cuyahoga County Building Card Index, Cuyahoga County Archives, Cleveland.

certain that the couples became acquainted and that the Copeses related their Cleveland Heights experiences. Ironically, both couples had moved from Mt. Pleasant to Glenville, but otherwise they were on different trajectories. The Copeses had pioneered black homeownership in Cleveland Heights but never won full acceptance despite seventeen years as model citizens. The Spencers' experience in the Heights was still on the horizon.

In 1957, the Spencers sold their Glenville home and, turning again to white intermediaries, purchased a 3,300-square-foot brick Tudor Revival home at 2473 Edgehill Road in the Euclid Heights allotment (see Figure 14). ${ }^{74}$ In April, soon after they moved in, the Spencers suffered the first in a series of menacing incidents when someone slashed two tires on their car. Over the next three months, additional incidents kept them on edge. An unknown person or persons hurled a kerosene bomb that "landed harmlessly outside the home," tore up plants in their garden, and lobbed a stench bomb (a glass jar filled with vinegar, horseradish, and mustard) through their living room window. Cleveland Heights policemen dismissed the acts as the work of unruly juveniles. The harassment continued, including having dirt dumped on their driveway and someone driving a hearse past the house every night. Mayor Ken Nash later insinuated that the Spencers were making unreasonable demands of his police department. He averred that when the city had received a concerned call from "one of the Negro judges downtown," "[w]e told the judge we'd give him [Spencer] the same protection that any other citizen has." The mayor added, approvingly, "He keeps his place up; I never see anybody around there. . . . Of course the bad thing about that was the subterfuge that he used to get in." As with the Dixons, the Spencers were 
blamed for daring to obtain their civil rights by breaking the rules. The Spencers were the last African Americans to buy in Cleveland Heights until the architect Robert P. Madison built on North Park Boulevard in 1960, and they occupied their home until 1981. ${ }^{75}$

\section{Black in the Heights: Social Life and Social Mobility}

The African American presence in Cleveland Heights did not automatically translate into a cohesive community. Although blacks numbered 571 in 1930, they hovered around 1 percent of the population between 1900 and 1960 . In addition, their persistence rate was very low, especially among servants. In 1940, only 5.5 percent of blacks in Cleveland Heights had lived there ten years before. Of ninety-one individuals from the 1940 census who could be positively identified in the 1950 city directory, just nine remained in the suburb. Thirty-two moved to Cedar-Central, a hint of downward mobility, while forty-two went to Glenville or Mt. Pleasant, where they found solid but aging housing in neighborhoods no longer viewed as desirable by most whites. Finally, very few blacks were in homeowning families, although the percentage grew slowly from 0.7 percent in 1930 to 6.8 percent in $1960 .^{76}$

Cleveland Heights blacks inhabited social worlds fragmented by class and geography. Domestic service workers and spouses with industrial jobs worked long hours, leaving scarce time for social interaction. In addition, they had little in common with homeowners. Having a suburban address did little to reorient African Americans from the few Cleveland neighborhoods with the vast majority of stores, restaurants, nightspots, religious institutions, and fraternal organizations that supported black communities. For most domestic service workers, where they were from and where they stayed were not the same. To make matters worse, Cedar and Mayfield Roads, the arteries that connected Cleveland Heights with Cleveland, became focal points for racial attacks in the 1950 s, when whites felt increasingly threatened by the approaching lines of racial residential turnover. ${ }^{77}$

In contrast, African American homeowners in Cleveland Heights forged a sense of community rooted in memberships in professional associations and social organizations and social gatherings they hosted in their homes and gardens. Newspaper society columns paint an impressionistic picture of these social circles. For the first homeowners, Alfred and Mayme Copes, entertaining in the 1920s necessitated inviting friends or family from Cleveland or from out of town. Starting in the $1930 \mathrm{~s}$, friendships among Cleveland Heights black homeowners were evident. The most popular gathering place seems to have been the Wises' house, which hosted many dinner parties and other social functions. ${ }^{78}$ The fact that six of the eight black men who owned Cleveland Heights homes were physicians provided additional linkages, some of which predated and possibly influenced their decisions to move to the suburb. For example, Drs. Wise and Wallace, both native Texans, graduated from Meharry Medical College a year apart. Drs. Baumgardner and Evans interned together at Freedmen's Hospital in Washington, DC, and Myrtle Baumgardner was Evans's daughter Barbara's godmother. ${ }^{79}$ Most and possibly all of the doctors shared membership in the Cleveland Medical Association, and their wives were active in the Auxiliary of Allied Medical Professions. Drs. Wise and Harris, and perhaps others, belonged to the Forest City Golf Club. As mentioned, Alfred and Mayme Copes were connected to Effie Baxter and Edgar and Effie Dixon through blood or marriage and surely shared each other's achievements and hardships in their respective struggles for suburban homeownership.

It was difficult enough to create a collective identity as black residents in Cleveland Heights, so one should not assume that the early owners pressed for more systemic change in housing. The precarity of their own housing victories left blacks with little latitude for serving as advocates for broader access to suburban housing. Two early black Cleveland Heights homeowners even appeared unwilling to challenge racism within Cleveland proper. In 1954, the Call \& Post reported that Dr. Wallace owned a large apartment building in Glenville but refused to rent to 


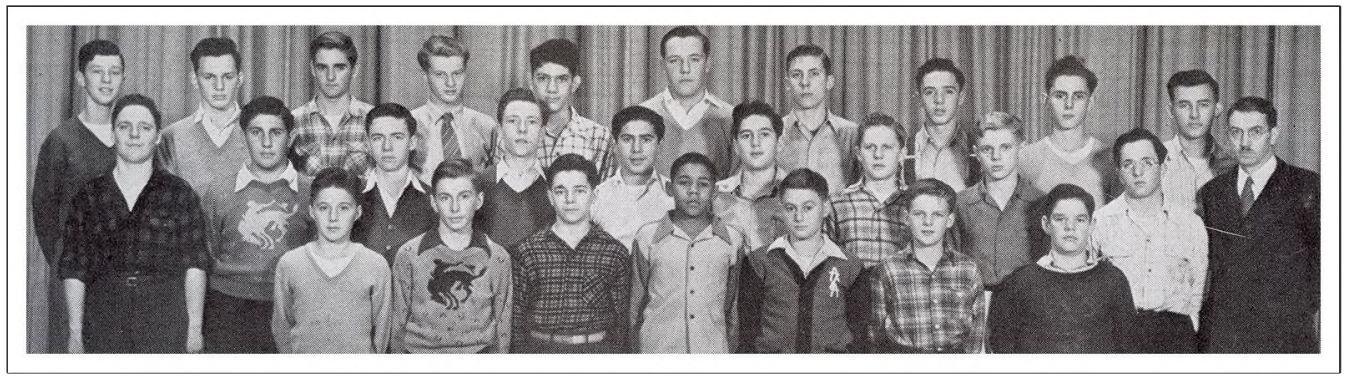

Figure 15. Alonzo Gordon Wright Jr. at Heights High, 1946. Alonzo Gordon Wright Jr.'s parents were only the third African American homeowner family in Cleveland Heights, but he was hardly the first black youth to attend the Heights schools. The earliest known black student had graduated in 1932, and at least a dozen black students attended the high school from the 1930s through the 1950s.

Source: Cleveland Heights High School Caldron, 1946.

blacks for fear of losing his white tenants. Similarly, in 1961, Ebony magazine's feature on Wright included a photo of one of Wright's many rental properties in Cleveland and pointed out that it was white-occupied. ${ }^{80}$ One white Cleveland Heights resident and early fair housing advocate, who spoke on the condition of anonymity in 1962, said that Wright might facilitate integration in Cleveland Heights and Shaker Heights if only he would loan to black home buyers, but, the man lamented, "he just didn't want any part of it. He's got his farm out in the country and... I think that disturbed me a little bit." ${ }^{\text {"1 } 1}$ Yet, the presence of a handful of longtime black homes over a period of decades was inherently influential in that it mirrored one tactic of the fair housing effort - to achieve some dispersion of black buyers throughout the suburbs to counter the pattern of rapid racial turnover.

Those who overcame the obstacles in their way could provide their children a superior education in an acclaimed school system. At least twelve African Americans attended Heights schools in the 1930s-1950s (see Figure 15). The earliest may have been Dorothy Ormes, who graduated from Cleveland Heights High School in 1932. The daughter of apartment building custodian Barney Ormes and his wife Parthenia, she lived at 2517 Overlook Road, just a block from where the formerly enslaved Jane Robinson toiled for Patrick Calhoun thirty years earlier. Adolphus Morris and William Thompson, sons of Hampshire Road apartment custodians, graduated in 1934. Several other homeowners' and custodians' children did likewise in the 1940s-1950s. The Evans sisters went from Heights High to become Phi Beta Kappa alumnae of Flora Stone Mather College of WRU, with Margaret also earning a master's in Spanish from Wisconsin, while the Baumgardner sisters completed undergraduate and master of social work degrees, Gretchen at WRU and Jane at Smith College and NYU. ${ }^{82}$

\section{Conclusion}

One wishes for opportunities, lost decades ago, to conduct oral histories to help flesh out the contestation of the color line in the decades before the most active phase of the Civil Rights movement. The accomplishment of lifting the ivory curtain by buying and holding onto a suburban house long enough to make it a home deserves more investigation than the scant record allows. But for the recovery of their stories, albeit incomplete, the history of Cleveland Heights integration would emerge only with the second generation of pioneers in the 1960s. Madison's move would remain widely seen as the first black integration of Cleveland Heights despite the fact that Alfred Copes built his home on Princeton Road thirty-seven years earlier. In short, the preceding examination of black suburbanization provides a necessary reframing of a timeline that persists for one of the nation's leading models of suburban racial integration. 


\section{Acknowledgments}

The author wishes to thank Todd M. Michney, Susan Kaeser, and Virginia P. Dawson for their helpful coments on drafts of this article.

\section{Declaration of Conflicting Interests}

The author(s) declared no potential conflicts of interest with respect to the research, authorship, and/or publication of this article.

\section{Funding}

The author(s) received no financial support for the research, authorship, and/or publication of this article.

\section{ORCID iD}

J. Mark Souther (1D) https://orcid.org/0000-0001-8090-7056

\section{Notes}

1. "Ask Housing Bars Down for Negroes," Plain Dealer, February 22, 1957.

2. Ken S. Nash, interview by Maurice Klain, 1962, transcript, 212-18, Maurice Klain Research Papers: Cleveland Area Leadership Studies, Series I, MS 4219 (hereinafter MKRP), container 9, folder 474, Western Reserve Historical Society, Cleveland, OH; Interview \#294, MKRP. Maurice Klain was a political science professor at Western Reserve University who received a major Ford Foundation grant to research the civic power structure in metropolitan Cleveland. Klain conducted confidential interviews that he later deposited at Western Reserve Historical Society. Most remain restricted, but through the efforts of John J. Grabowski and this author, some interviewee descendants have waived restrictions. In cases where restrictions remain, a randomized numbering system is used and no explicit reference is made to the interviewee. For context on University Circle as a buffer, see J. Mark Souther, Believing in Cleveland: Managing Decline in "The Best Location in the Nation" (Philadelphia: Temple University Press, 2017), 54-55.

3. W. Dennis Keating, The Suburban Racial Dilemma: Housing and Neighborhoods (Philadelphia: Temple University Press, 1994), chaps. 4, 6, 7.

4. Kenneth T. Jackson, Crabgrass Frontier: The Suburbanization of the United States (New York: Oxford University Press, 1985), 225.

5. Andrew Wiese, Places of Their Own: African American Suburbanization in the Twentieth Century (Chicago: The University of Chicago Press, 2004), 25-27, 34-36, 54-65.

6. Thomas Meehan, "The Good Life in Shaker Heights," Cosmopolitan, March 1963, 46-51; Joseph P. Blank, "Ludlow-A Lesson in Integration," The Reader's Digest, September 1968, 194.

7. John R. Stilgoe, Borderland: Origins of the American Suburb, 1820-1939 (New Haven: Yale University Press, 1988), 239-51; Kenneth Kolson, Big Plans: The Allure and Folly of Urban Design (Baltimore: Johns Hopkins University Press, 2003), 65-74; James Borchert, "Downtown, Uptown, Out of Town: Diverging Patterns of Upper-class Residential Landscapes in Buffalo, Pittsburgh, and Cleveland, 1885-1935," Social Science History 26, no. 2 (Summer 2002): 311-46; Robert M. Fogelson, Bourgeois Nightmares: Suburbia, 1870-1930 (New Haven: Yale University Press, 2007); Virginia P. Dawson, "Protection from Undesirable Neighbors: The Use of Deed Restrictions in Shaker Heights, Ohio," Journal of Planning History 18, no. 2 (May 2019): 116-36; Shelley Stokes-Hammond, "Recognizing Ludlow-A National Treasure: A Community That Stood Firm for Equality" (MA thesis, Goucher College, 2011); Cynthia Mills Richter, "Integrating the Suburban Dream: Shaker Heights, Ohio" (PhD diss., University of Minnesota, 1999). The best examination of the outer-city neighborhoods of Glenville, Mt. Pleasant, and Lee-Harvard that provided suburblike lifestyles for African Americans in the years before homeownership in Shaker and Cleveland Heights and other suburbs became more attainable is Todd M. Michney, Surrogate Suburbs: Black Mobility and Neighborhood Change in Cleveland, 1900-1980 (Chapel Hill: The University of North Carolina Press, 2017). 
8. Keating, Suburban Racial Dilemma; Marian J. Morton, Cleveland Heights: The Making of an Urban Suburb (Charleston, SC: Arcadia Publishing, 2002); Susan Kaeser, Resisting Segregation: Cleveland Heights Activists Shape Their Community, 1964-1976 (Cleveland: Cleveland Landmarks Press, 2020).

9. Kenneth L. Kusmer, A Ghetto Takes Shape: Black Cleveland, 1870-1930 (Urbana: University of Illinois Press, 1976), 168.

10. See, for example, Tera W. Hunter, To 'Joy My Freedom: Southern Black Women's Lives and Labors After the Civil War (Cambridge: Harvard University Press, 1997), vii-viii; Talitha LeFlouria, Chained in Silence: Black Women and Convict Labor in the New South (Chapel Hill: The University of North Carolina Press, 2015), 15-17.

11. On Euclid Heights, see Kara Cathleen Hamley, "Cleveland's Park Allotment: Euclid Heights, Cleveland Heights, Ohio, and Its Designer, Ernest W. Bowditch" (MA thesis, Cornell University, 1996); William C. Barrow, "The Euclid Heights Allotment: A Palimpsest of the Nineteenth Century Search for Real Estate Value in Cleveland's East End" (MA thesis, Cleveland State University, 1997). On Calhoun in San Francisco, see Joanna L. Dyl, Seismic City: An Environmental History of San Francisco's 1906 Earthquake (Seattle: University of Washington Press, 2017), 173.

12. On African Americans going straight to borderland areas along or beyond the outer fringes of cities, including Cleveland, see Wiese, Places of Their Own, and Michney, Surrogate Suburbs.

13. 1920 U.S. Census of Population, Ohio, vol. 61, reel 1374, National Archives and Records Administration (hereinafter NARA), Internet Archive (hereinafter IA). The official 1930 census figure for Cleveland Heights was 573, but the enumerators accidentally recorded William and Maud Dixon at 2740 Euclid Heights Boulevard twice, inflating the overall number by two.

14. 1900 U.S. Census of Population, Ohio, vol. 38, reel 1260, NARA, IA; The Cleveland Blue Book (Cleveland: Helen DeKay Townsend, 1899), 167, Cleveland Public Library (hereinafter CPL).

15. 1910 U.S. Census of Population, Ohio, vol. 30, reel 1164, NARA, IA.

16. 1920 U.S. Census; Mazie Adams, "Drive by History: The Painter Estate," View from the Overlook: The Journal of the Cleveland Heights Historical Society 13 (Spring 2007): 1, 3, accessed July 21, 2020, http://chhistory.org/blog/wp-content/uploads/2014/03/CHHS-News_Spring2007-HR.pdf. Illegibility of portions of some manuscript census pages prevents an exact count.

17. 1930 U.S. Census of Population, Ohio, vols. 76-77, reels 1783-84, NARA, IA; 1940 U.S. Census of Population, accessed June 29, 2020, https://1940census.archives.gov. On Jewish migration from Glenville to Cleveland Heights, see J. Mark Souther, "Jewish Suburbanization and Jewish Presence in the "City without Jews," in Cleveland Jews and the Making of a Midwestern Community, ed. Sean Martin and John J. Grabowski (New Brunswick, NJ: Rutgers University Press, 2020), 162-82. On Jewish expansion east of South Taylor Road, see Robert K. Nelson et al., "Mapping Inequality," ed. Robert K. Nelson and Edward L. Ayers. American Panorama, accessed July 21, 2020, https://dsl. richmond.edu/panorama/redlining/ $\#$ loc $=14 / 41.506 /-81.576 \&$ city $=$ cleveland-oh\&area $=\mathrm{A} 27, \quad$ https:// dsl.richmond.edu/panorama/redlining/\#loc $=14 / 41.506 /-81.576 \&$ city $=$ cleveland-oh\&area $=B 38$.

18. "The Lindbergh Kidnaper," Call \& Post, September 29, 1934; "Briefs Asked in Case of Domestics Ousted and Charged with Trespassing," Call \& Post, February 5, 1949.

19. "Heights Home Holds 2 Girls in Peonage," Call \& Post, February 3, 1938.

20. "Maid Wants Decree from Gambling Husband," Call \& Post, August 27, 1936.

21. 1920 U.S. Census; 1930 U.S. Census.

22. 1920 U.S. Census; 1930 U.S. Census; 1940 U.S. Census.

23. "On \& Off the Boulevard: The Grand Apartments of Cleveland Heights," accessed July 21, 2020, https://www.clevelandheights.com/243/Grand-Apartments.

24. 1920 U.S. Census; 1929 Cleveland City Directory, CPL; 1930 U.S. Census; 1940 U.S. Census.

25. 1930 U.S. Census; 1940 U.S. Census; This finding contrasts with Marian Morton's speculation that the decline of live-in servants in mansions accounts for the black population decrease; see Morton, Cleveland Heights, 126.

26. "Places of their own" is derived from Wiese, Places of Their Own.

27. 1920 U.S. Census; 1930 U.S. Census; 1940 U.S. Census.

28. 1920 U.S. Census; Erin Rothenbuehler, "Wheeling-born Maestro Celebrates 100th Birthday," Archiving Wheeling, August 31, 2016, accessed July 18, 2020, http://www.archivingwheeling.org/blog/ happy100theverettlee; Carol J. Oja, "Everett Lee and the Racial Politics of Orchestral Conducting," 
American Music Review 43, no. 1 (Fall 2013): 1-7, accessed July 18, 2020, http://www.brooklyn.cuny. edu/web/academics/centers/hitchcock/publications/amr/v43-1/oja.php\#note3.

29. Jos. M. Goldwasser, "Peerless Points Out: Where There's a Will, There's Everett Lee and Family," Call \& Post, November 10, 1945; "Everett Lee Wins City Violin Contest," Call \& Post, May 12, 1934; 1938 Cleveland City Directory, CPL.

30. Oja, "Everett Lee."

31. Kusmer, A Ghetto Takes Shape, 165-66; Morton, Cleveland Heights, 126.

32. "Fenderson R. Copes; Born in Slavery; Obituary," Oberlin News, August 5, 1914; "Fenderson R. Copes," in 1870 U.S. Census of Population, M593, roll 1235, p. 616A, Russia, Lorain, OH, NARA, Ancestry.com.

33. "Alfred Copes," in 1900 U.S. Census of Population, T623, roll 1294, p. 30A, Lorain Ward 4, Lorain, OH, District 70, NARA, Ancestry.com; "Alfred Copes," in 1910 U.S. Census of Population, T624, roll 1206, p. 13B, Oberlin Pct. 1, Lorain, OH, District 124, NARA, Ancestry.com; Alfred Copes and Mayme Yates Marriage License, June 2, 1915, Ohio, County Marriage Records, 1774-1993, Ancestry. com; 1917-18 Cleveland City Directory, CPL; "Alfred Copes," in 1920 U.S. Census of Population, T625, roll 1368, p. 14A, Cleveland Ward 16, Cuyahoga, OH, District 316, NARA, Ancestry.com.

34. Frank Diermayer to Mayme E. Copes, deed recorded March 20, 1923, AFN\# 192303190050, book 2770 , p. 579, Cuyahoga County Recorder Office (hereinafter CCRO); Shaker Lakes Subdivision ad, Plain Dealer, August 28, 1910; Building Permit 12472, Building Permit Database (hereinafter BPD), City of Cleveland Heights Department of Planning and Development.

35. Berwald-Stewart Co to Board of Education of Cleveland Heights Village School District, deed recorded January 18, 1921, AFN\# 192101180011, book 2461, p. 162; "80 Guests Join Copes' on 25th Anniversary," Call \& Post, June 8, 1940; 1939 Cleveland City Directory, CPL; 1940 Cleveland City Directory, CPL.

36. Robert T. Wise Draft Registration Card, Draft Board 2, Bell County, Texas, roll 1927365, U.S. World War I Draft Registration Cards, 1917-1918, Ancestry.com; "Tom Wise," in 1870 U.S. Census, M593, roll 166, p. 140A, Monroe, Georgia, NARA, Ancestry.com; Tom Wise and Ida Daniels Marriage License, Spalding County Record of Marriages, Book C, 1882-1893, Georgia Marriage Records from Select Counties, 1828-1978, Ancestry.com; "Robert Wise," in 1910 U.S. Census, T624, roll 1575, p. 2B, Justice Precinct 2, McClennan, TX, District 95, NARA, Ancestry.com; "Services Held for Dr. Robert T. Wise," Call \& Post, January 27, 1968; "Robert T. Wise," in 1930 U.S. Census, Ohio, vol. 76, reel 1783, p. 15A, Cleveland Heights CH-6, Cuyahoga, OH, District 18-561, NARA, IA; 1921 Cleveland City Directory, CPL.

37. Real estate ad, Plain Dealer, July 4, 1925; Jacob and Lena Roodman to Samuel Friedman, deed recorded May 22, 1926, AFN\# 192605220176, book 3401, p. 453, CCRO; Real estate ad, Plain Dealer, October 17, 1926.

38. Samuel and Ida Friedman to Saul Greenberg, deed recorded August 1, 1927, AFN\# 192708010049, book 3523, p. 222, CCRO; Saul Greenberg to Lula B. Wise, deed recorded August 3, 1927, AFN\# 192708030056, book 3525, p. 47, CCRO; Lulu B. Wise to Leon A. Greenberg, deed recorded December 24, 1927, AFN\# 1927122240084, book 3589, p. 150, CCRO; Leon A. Greenberg to Richard Baldwin, deed recorded March 17, 1928, AFN\# 192803170146, book 3528, p. 529, CCRO; Richard Baldwin to Lulu B. Wise, deed recorded April 3, 1928, AFN\# 192804030183, book 3595, p. 476, CCRO.

39. 1929 Cleveland City Directory, CPL; Stanley Adelstein, "A Fine Addition to the Neighborhood," in J. Mark Souther, "Grant Deming's Forest Hill," Cleveland Historical, May 5, 2012, accessed July 5, 2020, https://clevelandhistorical.org/items/show/447, excerpted from Stanley Adelstein interview, 2002, City of Cleveland Heights Oral History Project.

40. Nelson et al., "Mapping Inequality," accessed July 23, 2020, https://dsl.richmond.edu/panorama/ redlining/\#loc $=14 / 41.502 /-81.595 \&$ city $=$ cleveland-oh\&area $=B 37 ; 1930$ Census.

41. "Mrs. Lula Wise, Wife of Doctor, Dies at Home," Call \& Post, September 18, 1954: "Services Held for Dr. Robert T. Wise," Call \& Post, January 27, 1968; Robert T. Wise-Deceased to Esther Wise, certificate of transfer recorded September 17, 1968, AFN\# 00207299, book 12357, p. 135, CCRO; Esther Wise to Frits and Betty F. van der Kuyp, deed recorded February 11, 1972, AFN\# 00492842, book 12971, p. 285, CCRO.

42. Alonzo G. Wright and Henrietta B. Cheeks Marriage License, July 18, 1929, Ohio, County Marriage Records, 1774-1993, Ancestry.com. 
43. "Alonzo Wright," in 1900 U.S. Census, T623, roll not listed, p. 20, Civil District 8, Lincoln, TN, District 62, NARA, Ancestry.com; "Cleveland Millionaire," Ebony, August 1, 1961, 41; "Alonzo Wright," in 1920 U.S. Census, T625, roll 1363, p. 2A, Cleveland Ward 9, Cuyahoga, OH, District 163, NARA, Ancestry.com.

44. Harry Stainer, "Is He a Millionaire? Wright 'Guesses' So," Plain Dealer, May 31, 1962; Wright and Cheeks Marriage License; "Henrietta Cheeks," in 1920 U.S. Census, T625, roll 1370, p. 1A, Cleveland Ward 19, Cuyahoga, OH, District 393, NARA, Ancestry.com; 1926 Cleveland City Directory, CPL; 1929 Cleveland City Directory, CPL; Henry Hallock to Alonzo G. Wright, deed recorded October 15, 1928, AFN\# 192810150142, book 3798, p. 89, CCRO.

45. Stainer, "Is He a Millionaire?"; "Cleveland Millionaire," 42; "Alonzo Wright, Business Pioneer, Dead," Call \& Post, August 21, 1976.

46. Alonzo G. Wright to Hermina Keller, deed recorded June 21, 1929, AFN\# 192906210136, book 3942, p. 273, CCRO; Hermina Keller to Ethel S. Obey, deed recorded August 30, 1929, AFN\# 192908300088, book 3946, p. 68, CCRO; Henrietta B. Wright to Ethel S. Obey, deed recorded December 9, 1929, AFN192912090040, book 3976, p. 430, CCRO; Ethel S. Obey to Henrietta B. Cheeks, deed recorded December 10, 1929, AFN\# 192912100056, book 3976, p. 440, CCRO; Charles Obey to Henrietta C. Wright, deed recorded May 25, 1931, AFN\# 193105250038, book 4149, p. 234, CCRO; "Alonzo G. Wright," in 1930 U.S. Census, Ohio, vol. 76, reel 1783, p. 8A, Cleveland Heights CH-11, Cuyahoga, OH, District 18-569, NARA, IA.

47. Marjorie Drexel Ison, "The Social Ladder," Call \& Post, July 28, 1938; Stainer, "Is He a Millionaire?"; "Alonzo Wright, Business Pioneer"; Cleveland Heights High School Caldron (hereinafter Caldron), 1947, 63, Lee Road Library, Cleveland Heights, OH (hereinafter LRL): Dawson, "Protection from Undesirable Neighbors," 127.

48. Cedar Heights Land Co. to Louise Canneville Evans, deed recorded August 13, 1925, book 3371, p. 373, CCRO; Mutual Building \& Investment Co. to Endor A. Harris, deed recorded July 27, 1931, book 4169 , p. 656 , CCRO.

49. Louise Canneville Evans and Armen G. Evans to Clarence G. Mack, deed recorded June 29, 1931, book 4164, p. 463, CCRO; Building Permit 21734, BPD; Clarence G. Mack and Florence Mack to Cornelia F. Nickens, deed recorded October 28, 1931, book 4204, p. 582, CCRO; Cornelia F. Nickens and James K. Nickens to Louise Canneville Evans and Armen Evans, deed recorded August 31, 1944, book 5804 , p. 337, CCRO.

50. "Armen Evans," in 1900 U.S. Census, T623, roll not listed, p. 13, Cleveland Ward 21, Cuyahoga, OH, District 99, NARA, Ancestry.com; "Armen G. Evans," in 1910 U.S. Census, T624, roll 1173, p. 3B, Cleveland Ward 19, Cuyahoga, OH, District 285, NARA, Ancestry.com; "Armen G. Evans," in 1920 U.S. Census, T625, roll 1369, p. 10A, Cleveland Ward 18, Cuyahoga, OH, District 372, NARA, Ancestry.com; "Cornelia Nickens," in 1930 U.S. Census, T626, roll not listed, p. 13B, Cleveland Ward 18. Cuyahoga, OH, District 18-349, NARA, Ancestry.com; "Armen Evans," in 1930 U.S. Census, T626, roll not listed, p. 13A, Cleveland Ward 18, Cuyahoga, OH, District 18-349, NARA, Ancestry. com.

51. "W.R.U. Graduates More Than 300," Plain Dealer, June 13, 1920.

52. "Dr. Hardie F. Harris Dies; Rites Saturday," Call \& Post, June 9, 1956; "Endor Sheppard," in 1900 U.S. Census, T623, roll not listed, p. 8B, Macon, Noxubee, MS, District 67, NARA, Ancestry.com; "Hardie Harris," in 1910 U.S. Census, T624, roll 4, p. 18A, Anniston Ward 2, Calhoun, AL, District 22, NARA, Ancestry.com; "Hardy F. Harris," in 1920 U.S. Census, T625, roll 1105, p. 7A, Buffalo Ward 20, Erie, NY, District 182, NARA, Ancestry.com; 1929 Cleveland City Directory, CPL; Cedar Heights Land Co. to Ruth Siegel, deed recorded April 5, 1928, book 3574, p. 589, CCRO; Louis R. Siegel et al. to Ethel Desberg, deed recorded April 17, 1929, book 3807, p. 119, CCRO; Ethel Desberg to Helen Gross, deed recorded March 14, 1930, book 3983, p. 59, CCRO; 1930 U.S. Census, Ohio, vol. 77, reel 1784, p. 17B, Cleveland Heights CH-17, Cuyahoga, OH, District 18-582, NARA, IA; 1936 Cleveland City Directory, CPL; "Hardie F. Harris," in 1940 U.S. Census, T627, roll not listed, p. 2A, Cleveland Ward 29, Cuyahoga, OH. District 92-737, NARA, Ancestry.com. Both Harris and Evans were listed as "Mulatto" in the 1910 census. By 1930, Harris claimed to be "Negro" while Evans reported being "White." It is not clear how the property that the Harrises bought passed from Desberg to the Mutual Building \& Investment Co. 
53. BPD; Caldron, 1944, 37, LRL; Caldron, 1946, 36, LRL; "Louise C. Evans," in Ohio Department of Health, Index to Annual Deaths, 1958-2002, Ancestry.com.

54. "Dr. Baumgardner Dies," Call \& Post, January 17, 1976; Dr. Baumgardner to Head Physicians Meeting in D.C.," Call \& Post, June 3, 1961; "Luther O. Baumgardner," in 1900 U.S. Census, T623, roll not listed, p. 7, Manning, Clarendon, SC, District 8, NARA, Ancestry.com; "Professional Notice," Southern Indicator [Columbia, SC], December 17, 1921; "Joseph C. Robinson," in 1910 U.S. Census, T624, roll not listed, Cleveland Ward 25, Cuyahoga, OH, District 385, NARA, Ancestry.com; "Joseph C. Robinson," in 1920 U.S. Census, T625, roll not listed, p. 12A, East Cleveland Ward 1, Cuyahoga, OH, District 330, NARA, Ancestry.com; "Luther O. Baumgardner," in 1930 U.S. Census, T626, roll not listed, p. 11A, East Cleveland Ward 1, Cuyahoga, OH, District 585, NARA, Ancestry.com.

55. Theresa Burg and Sol Burg to C. J. Condon and Sarah Condon, deed recorded December 20, 1937, book 4809, p. 647, CCRO; C. J. Condon and Sarah Condon to Luther O. Baumgardner and Myrtle L. Baumgardner, deed recorded December 20, 1937, book 4809, p. 649, CCRO. The Burgs signed the transfer document on August 17, 1937, and the Condons signed the second document on September 10,1937 , meaning that the recording dates are deceptively late in these examples.

56. "Hurl Bomb at Dwelling on Heights," Plain Dealer, August 28, 1938; "Bombing in Cleveland Heights," Call \& Post, September 1, 1938; "Doctor's Yard Bombed as Hurlers Miss Mark," Dayton Forum, September 9, 1938.

57. "Ku Kluxers Hurl a Bomb at Dr. Baumgardner's New Home in the Heights," Cleveland Gazette, September 3, 1938.

58. Caldron, 1948, 46, LRL; Caldron, 1955, 101, LRL; “Dr. Baumgardner Dies," Call \& Post, January 17, 1976.

59. Harold Freeman to Effie M. Dixon, deed recorded June 1, 1936, AFN\# 193606010143, book 4615, p. 62, CCRO; Credit Men's Adjustment Bureau Co. to Effie Baxter, deed recorded September 29, 1938, AFN\# 193809290065, book 4874, p. 16, CCRO. It is worth noting that Blanche Johnson, another black homeowner, lived on Tullamore Road just across the city border in University Heights; see "Blanche E. Johnson Home from Hospital," Call \& Post, February 14, 1942; 1938 Cleveland City Directory, CPL.

60. "Effie Yates," in Ohio, Births and Christenings Index, 1774-1973, Ancestry.com; "Effie Yates," in 1900 U.S. Census, T623, roll not listed, p. 8, Cleveland Ward 19, Cuyahoga, OH, District 84, NARA, Ancestry.com; Edgar Dixon and Effie M. Yates Marriage License, November 14, 1924, "Effie Yates," in Cuyahoga County, Ohio, Marriage Records and Indexes, 1810-1973, vol. 137-138, p. 249, reel 76, Ancestry.com; "Edgar N. Dixon," in 1930 U.S. Census, T626, roll not listed, p. 9A, Cleveland, Cuyahoga, OH, District 356, NARA, Ancestry.com; 1930 Cleveland City Directory, 1930, CPL; Charles H. Loeb, "Bomb Blasts Home of Negro in Heights," Call \& Post, June 29, 1939; "Resume of Facts regarding Experience of Effie M. Dixon in Purchase of Land in Cleveland Park [sic], Ohio, 19361939," Group I, Box C-404, Subject File - Segregation - Residential, General, January 6-November 19, 1939, reel 1, frame 1028, Papers of the NAACP, Library of Congress. The assumption about the Dixons' move to live with her sister and brother-in-law draws from a comment in Mrs. Dixon's notes in 1939 about having "lived for seven years about four blocks from the new house," a reference to the home they were attempting to build for themselves on Northcliffe Road.

61. "Bomb Blasts Home of Negro in Heights; Cleveland Bank Moves to Break Contract After Blast," Call \& Post, June 29, 1939; "Resume of Facts."

62. "Resume of Facts"; Effie M. Dixon to Joseph J. Atto, deed recorded February 5, 1939, AFN\# 193902030081 , book 4922, p. 628, CCRO; Second Federal Savings and Loan Association of Cleveland v. Joseph J. Atto, Keith Lawrence, as Trustee, Edgar N. Dixon, and Effie M. Dixon, in the Court of Common Pleas, C.F. 488700 C. of A. 17816, May Term 1939 (hereinafter Second Federal v. Atto et al.), Answer and Cross-Petition, filed October 21, 1939, recorded vol. 1750, p. 473, Cuyahoga County Clerk of Courts (hereinafter COC).

63. Second Federal v. Atto et al., Supplemental Petition of Plaintiff, filed January 19, 1940, recorded vol. 1750, p. 488 "Resume of Facts"; "Bomb Blasts Home of Negro in Heights."

64. "Bomb Blasts Home of Negro in Heights"; Second Federal v. Atto et al., Reply Brief of Plaintiff on Demurrer, filed September 21, 1939, recorded vol. 1750, p. 464, COC; Second Federal v. Atto et al., Answer and Cross-Petition, filed October 21, 1939, recorded vol. 1750, p. 473, COC. 
65. "Bank Moves to Foreclose on Negro Home in "the Heights," Call \& Post, July 6, 1939; "Dixon Case Discloses Jim-Crow Policy of Cleveland's Banks," Call \& Post, February 22, 1940.

66. Second Federal v. Atto et al., Reply Brief to Plaintiff"s Demurrer (by Clayborne George and Chester K. Gillespie), filed September 21, 1939, recorded vol. 1750, p. 464, COC: Second Federal v. Atto et al., Answer and Cross-Petition, filed October 21, 1939, recorded vol. 1750, p. 473, COC.

67. Second Federal v. Atto et al., Demurrer of Plaintiff to Cross Petition of Defendants Dixon-Brief and Notice, filed October 9, 1939, recorded vol. 1750, p. 461; Second Federal v. Atto et al., Reply Brief of Plaintiff, filed November 20, 1939, recorded vol. 1750, p. 484, COC.

68. Second Federal v. Atto et al., Docket and Journal Entries, filed March 15, 1940, hearing transcript, February 29, 1940, journal 290, pp. 758, 1182-83, COC; Second Federal v. Atto et al., Consent of Parties to Dismissal, March 9, 1940, COC; 1940 Cleveland City Directory, CPL. "Surrogate suburb" derives from Michney, Surrogate Suburbs.

69. Building Permit 124929, BPD; "Bomb Blasts Home of Negro in Heights"; "Alfred B. Copes," in 1940 U.S. Census, T627, roll not listed, p. 9A, Cleveland Ward 30, Cuyahoga, OH, District 92-739, NARA, Ancestry.com; "Racial Prejudice Charged in Trial," Plain Dealer, October 29, 1941; "Loses Suburb Suit on Race Prejudice," Plain Dealer, November 4, 1941; "Cleveland Social and Personal," Cleveland Gazette, November 15, 1941; Effie Baxter to Lester Ciancibello, deed recorded November 17, 1942, AFN\# 194211170151, book 5476, p. 734, CCRO; Building Permit 27142, BPD; J. Walter Wills to Effie Baxter, deed recorded September 20, 1944, AFN\# 194409200145, book 5809, p. 654, CCRO; Effie Baxter to Mayme E. Copes and Alfred B. Copes, deed recorded February 18, 1952, AFN\# 195202180057, book 7448, p. 227, CCRO; 1940 U.S. Census. Wills helped many black home buyers secure loans; see Kimberley L. Phillips, AlabamaNorth: African-American Migrants, Community, and Working-Class Activism in Cleveland, 1915-45 (Urbana: University of Illinois Press, 1999), 135.

70. "Jesse Etta Wallace," in World War II Draft Cards (4th Registration) for the State of Ohio, Records of the Selective Service System. Record Group Number 147, The National Archives at St. Louis, St. Louis, MO, Ancestry.com; "Dr. Wallace, Prominent Cleveland Medic Passes," Call \& Post, May 31, 1969; "Lorena Phillips," in 1920 U.S. Census, T625, roll 1822, p. 10B, Cleburne Ward 4, Johnson, TX, District 42, NARA, Ancestry.com; 1929 Cleveland City Directory, CPL; "City's First Black Market Owner Buried in Texas," Call \& Post, March 17, 1973; 1940 Cleveland City Directory, CPL; Assunta and Alfonso Carfagna to Katie Vinocur, deed recorded October 5, 1934, AFN\# 193410050040, book 4385, p. 609, CCRO; Katie Vinocur to Martin G. Brown, deed recorded January 17, 1949, AFN\# 194901170102, book 6665, p. 103, CCRO; Martin G. Brown to Lorena T. Wallace and Jesse E. Wallace, deed recorded July 18, 1949, AFN\# 194907180257, book 6817, p. 17, CCRO.

71. Jesse E. Wallace-Deceased to Lorena T. Wallace, certificate of transfer recorded March 7, 1970, AFN\# 00950027, book 12594, p. 435, CCRO; Rathuel L. McCollum, admin. of Estate of Lorena T. Wallace, to Richard T. Andrews III and Rosalind T. Andrews, deed recorded March 6, 1981, AFN\# 00652448, book 15433, p. 313, CCRO.

72. "E. B. Spencer," in 1940 U.S. Census, Cleveland Ward 25, Cuyahoga, OH, pp. 4A, District 92-618, NARA, GenealogyBank; "Dr. Spencer is Buried," Call \& Post, May 26, 1983; "Emerald B. Spencer," in Ohio Department of Health, Index to Annual Deaths, 1958-2002, Ancestry.com.

73. Ethel Robbins to Arthur J. Carey, and Arthur J. and Theresa Carey to Marie C. Spencer, deeds recorded July 13, 1938, AFN\# 193807130077, vol. 4861, p. 481, CCRO; "E. B. Spencer," in 1940 U.S. Census.

74. Marie C. and E. B. Spencer to Manola S. Langrum, deed recorded June 25, 1957, book 8876, p. 43, CCRO; James L. and Muriel Bargar to Philip J. George, deed recorded December 27, 1956, AFN\# 195612270110, book 8816, p. 722, CCRO; Philip J. and Frances M. George to Florian and Ida Tresler, deed recorded April 16, 1957, book 8850, p. 589; Florian and Ida Tresler to Marie C. Spencer, deed recorded May 7, 1957, AFN\# 195705070125, book 8858, p. 217, CCRO.

75. "Probe Heights Stench Bombing," Plain Dealer, August 7, 1957; "Bomb Medic's Heights Home," Call \& Post, August 10, 1957; Interview \#80 by Maurice Klain, MKRP; Nash interview, transcript, 222-24; Emerald B. and Marie C. Spencer to Ljijana and Vasilije Lukic, deed recorded May 26, 1981, AFN\# 00675904, book 15453, p. 769, CCRO. On Madison's move to Cleveland Heights, see Robert 
P. Madison, interview by Timothy Klypchak, June 11, 2013," Cleveland Voices, accessed August 1, 2020, https://clevelandvoices.org/items/show/2413.

76. 1930 U.S. Census; 1940 U.S. Census; 1950 Cleveland City Directory, CPL.

77. See, for example, "Gang Beats Up Unarmed Youth in Hate Attack," Call \& Post, February 2, 1952; "“Mayfield Gang' Terrorist Gets Guilty Verdict," Call \& Post, February 16, 1952. For context, see Michney, "Race, Violence, and Urban Territoriality."

78. One of many examples, "Social Whirl," Call \& Post, October 7, 1944, describes a gathering in which the Wises hosted, among others, four current or soon-to-be Cleveland Heights homeowner couples, the Wrights, Evanses, Harrises, Baumgardners, and Spencers.

79. "Wallace, Jesse," Meharry Medical College Archives, accessed July 27, 2020, http://diglib.mmc.edu/ omeka/items/show/7592; "Wise, R.," Meharry Medical College Archives, accessed July 28, 2020, http://iglib.mmc.edu/omeka/items/show/9556; "Gets City Hospital Job," Call \& Post, November 3, 1934; "Dr. Armen Evans Buried Wednesday," Call \& Post, September 20, 1975; Valena Minor Williams, "The Cleveland Cosmopolite," Call \& Post, September 2, 1950.

80. "Wallace Assailed: Doctor's Exclusion of Negroes Hit by NAACP," Call \& Post, May 1, 1954; "The Case of Dr. Wallace," Call \& Post, May 8, 1954; "Black Millionaire," 43.

81. Interview \#140, MKRP.

82. Cleveland Heights Alumni Association database, courtesy of Eric Silverman; 1930 U.S. Census, Cleveland Heights CH-11, Cuyahoga, OH, District 18-571, NARA, IA; Caldron, 1920-1960, LRL; "CWRU Recognizes Its First Black Graduates," Call \& Post, February 19, 1987; "Gretchen Walker," Yellow Springs News (Yellow Springs, OH), December 19, 2009, accessed August 1, 2020, https:// ysnews.com/news/2009/12/gretchen-walker; "Leonard Savoy Weds Jane A. Baumgardner," New York Times, June 21, 1964.

\section{Author Biography}

J. Mark Souther is a professor of history and the director of the Center for Public History + Digital Humanities at Cleveland State University. He is the author of New Orleans on Parade: Tourism and the Transformation of the Crescent City (LSU Press, 2006) and Believing in Cleveland: Managing Decline in "The Best Location in the Nation" (Temple University Press, 2017). 